\title{
ADR Gone Wild: Is It Time for a Federal Mediation Exclusionary Rule?
}

\author{
Michael P. DiCKeY*
}

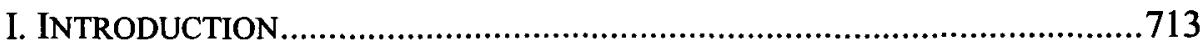

II. FOLDING MEDIATION INTO THE

DOCKET MANAGEMENT PROCESS ...................................................717

A. The Development of the Notion

of Mediation Good Faith. .721

B. Protecting Mediation Confidentiality

Under the Current Federal Rules

1. Rules-Based Approaches to Mediation Confidentiality

2. Common Law Recognition of

a Mediation Privilege

3. State Law Privilege Rules in Federal Court .741

III. THE EXPLOSION OF “GOOD FAITH" LITIGATION ................................744

IV. THE NEED FOR A RULE OF EXCLUSION:

ANSWERING THE "WHY" QUESTION 750

A. Policy-Based Arguments for an

Exclusionary Rule .751

B. Outcome-based Arguments for a

Rule of Exclusion .756

V. IMPLEMENTING A MEDIATION EXCLUSIONARY

RULE: ANSWERING THE "HOW" QUESTION 760

A. Common Law Mediation Privilege ........................................762

B. Statutory Mediation Privilege ...............................................764

C. Rule-Based Protection of Mediation

Confidentiality. 765

VI. CONCLUSION

VII. APPENDIX .770

\section{INTRODUCTION}

It was, pardon the pun, a signature image: a grainy photograph of a celebrity civil defendant, clad in grey jailhouse scrubs, signing a settlement agreement on the cot of his cinderblock cell. His incarceration was upon the order of a federal judge, not for violating a criminal law or committing an act of direct criminal contempt in court, but rather for engaging in bad faith 
misconduct at a confidential, court-ordered mediation of his civil case. The settlement agreement was the end result of negotiations that began with that mediation and ended with his decision to pay the plaintiffs a sum of money in the hope of regaining his freedom. Faced with the choice, as framed by one contemporaneous newspaper article, of "settle or jail," the defendant elected the former. This article explores how confidential mediation communications provided the factual basis for that dilemma, and suggests a vehicle for ensuring that this outcome never repeats itself.

Over the last quarter century, mediation has evolved from a flexible, informal dispute resolution vehicle into a process with its own values, norms, and expectations. With this evolution has come a growing body of laws and directives to guide participants and mediators, many of whom are further subject to ethical standards imposed by credentialing organizations. ${ }^{\text {T }}$ The guidance provided pursuant to this structure has resulted in court-ordered mediation developing into a largely uniform process across the various jurisdictions of this country.

As more and more cases have settled through mediation, courts and commentators increasingly perceive the mediation process as a means of managing congested dockets. ${ }^{2}$ Beginning with amendments to Rule 16 of the

- Assistant Professor, the Charleston School of Law. This article was presented at the New Scholars Workshop at the Southeastern Association of Law Schools Meeting on August 7, 2009. The author wishes to thank Rick Bales, Sheila Scheuerman, and Paul Lund for their time and insights during the preparation of this article. I am also grateful for the good work of my research assistants, Michael Callan Skinner and Josh Klinger. Any errors or omissions in the article are my own.

${ }^{1}$ For instance, in Florida mediators certified for circuit court-ordered mediations are certified pursuant to standards promulgated by the Florida Supreme Court's Dispute Resolution Center, which also provides ethics rules for mediators. Fla. R. Certified and Ct.-Appointed Mediators, Rule 10.100, et seq., http://www.flcourts.org/gen_public/adr/bin/RulesForMediators.pdf (last visited March 15, 2010). The rules for scheduling and conducting the mediation are contained in the Florida Rules of Civil Procedure. See FLA. R. CIV. P. 1.710, et seq. Finally, issues such as mediation confidentiality, and the exceptions to confidentiality, are addressed by statute. FLA. STAT. ANN. $§ 44.405$ (West 2010).

2 See Alternative Dispute Resolution and Settlement Encouragement Act; Federal Courts Improvements Act, and Need for Additional Federal District Court Judges: Hearing on H.R. 2603 and H.R. 2294 Before the Subcomm. on Courts and Intellectual Prop. of the H. Comm. on the Judiciary, 105th Cong. 5 (1997) [hereinafter "ADR Hearings on 2603 and 2294"] (stating, with regard to the goal of addressing "court congestion, delay and cost of litigation:" "In our judgment, this measure [H.R. 2603] could be improved significantly if we were to enlarge its scope by promoting and 


\section{IS IT TIME FOR A FEDERAL MEDIATION EXCLUSIONARY RULE?}

Federal Rules of Civil Procedure (FRCP) in $1983,{ }^{3}$ continuing with the Civil Justice Reform Act of $1990,{ }^{4}$ and culminating in the mandates of the ADR Act of 1998, federal courts integrated alternative dispute resolution generally, and mediation in particular, as a docket management tool. ${ }^{5}$ This integration glossed over an inherent limitation in a court's ability to mandate mediation-the confidentiality rules that almost universally applied to courtannexed mediation ${ }^{6}$ made it impossible, or at least very difficult, for a court to monitor the parties' compliance with its mediation order to the extent that the order sought to impose a standard of participation for the parties during the mediation.

Within the last decade, however, this limitation has effaced in response to increasing judicial intrusion into the mediation process. Perhaps the high water mark of this oversight of mediation from the bench came in the case of Doe v. Francis, ${ }^{7}$ in the U.S. District Court for the Northern District of Florida. There, Joe Francis, the principal of the Girls Gone Wild entertainment company (hereinafter GGW), ${ }^{8}$ Joe Francis, was held in contempt, and ultimately incarcerated for nearly a year, as a result of a chain

encouraging district courts, not only to use arbitration but to use other forms of alternative dispute resolution as well, and, in particular, mediation.').

${ }^{3}$ See In re Amendments to the Federal Rules of Civil Procedure, 97 F.R.D. 165, 210-11 (1983) advisory committee's note (discussing use of settlement conferences and extrajudicial techniques for purpose of facilitating settlement early in litigation). The Advisory Committee's discussion never mentions mediation, however, instead relying on the potential to refer the parties to "another member of the court or ... a magistrate," or the employment of "adjudicatory techniques outside the courthouse." Id.

4 The stated purpose of the district court plans developed pursuant to the Civil Justice Reform Act of 1990 (CJRA) was "to facilitate deliberate adjudication of civil cases on the merits, monitor discovery, improve litigation management, and ensure just, speedy, and inexpensive resolution of civil disputes." 28 U.S.C. $\$ 471$ (1990). This purpose was advanced, in the eyes of Congress, by "utilization of alternative dispute resolution programs in appropriate cases." Judicial Improvements Act of 1990, Pub. L. No. 101-650, § 102(D) (1990). In response to the ADR provisions of the CJRA, most district courts had implemented mediation programs by 1996. ELIZABETH PLAPINGER \& DONNA STIENSTRA, ADR AND SETTLEMENT IN THE FEDERAL DISTRICT COURTS 3 (1996).

5 This was, in fact, the stated purpose of the ADR Act of 1998. See Hearings, supra note 2, at 2 ("The effect of these changes will be to provide for a quicker, more efficient way to resolve some Federal cases when the parties so choose, and to lessen the incentive to litigate and, consequently, the caseload burdens faced by the Federal judiciary.").

${ }^{6}$ See infra Part V(B).

7 Doe v. Francis, 18 Fla. L. Weekly Fed. D 241 (N.D. Fla. Oct. 8, 2003).

${ }^{8}$ The actual entity that is behind the GGW entertainment brand is Mantra Films, LLC. Id. 
of events arising out of comments and behavior at a confidential mediation. In his contempt order, the judge went so far as to direct Francis regarding not only what he was allowed to say at mediation, but also his attire and choice of footwear. ${ }^{9}$ The Francis case could be treated as an anomaly, as it marks the only instance in which a mediation participant was jailed for his conduct at mediation. As this article will discuss, however, Francis is simply an extreme example of an otherwise entirely consistent trend in the federal district courts towards imposing judicial oversight upon the mediation process.

Paradoxically, federal courts have still adopted and enforced rules ostensibly meant to protect the confidentiality of mediation, and gone so far as to sanction parties for bringing motions that described what transpired or what was said at a mediation. 10 Thus, a litigant considering the filing of a sanctions motion based on her opponent's words or actions faces a dilemma: she may well succeed in obtaining sanctions against her opponent, or at least coloring the judge's perception of the opponent's case, through a motion that provides a factually detailed account of the events that took place behind the closed doors of a mediation. She may, on the other hand, find herself on the receiving end of a sanctions order simply for filing such a motion, should the court conclude that she has violated a local confidentiality rule or order.

This article proposes a partial reversal of the trend toward judiciallymanaged mediation, through the indirect method of adopting a proscription against using statements or conduct at mediation as a basis for most sanctions motions under the FRCP Rule 16. Part II of the article reviews generally the evolution of federal mediation rules and statutes, with particular attention to mediation's integration as a docket management tool. This development over the last two decades has led to the creation of widely divergent approaches to mediation confidentiality in the federal courts, with some courts adopting detailed rules and others relying on common law privilege principles, to the extent the courts preserve mediation confidentiality at all. The disparate treatment of mediation confidentiality, and its relationship to the courts' ability to monitor the parties' participation, has led perhaps inevitably to the explosion in motion practice related to mediation good faith described in Part III of this article. Part IV reviews the policy reasons for recognizing and implementing some form of a mediation confidentiality rule, highlighting the fact that the narrow understanding of the function of confidentiality reflected in federal rules and case law, often limiting it to the interests and principles

\footnotetext{
${ }^{9}$ Francis, 18 Fla. L. Weekly Fed. D at 241, Civil Minutes-General, at 4.

10 See infra text accompanying notes 190-92.
} 
advanced by Federal Rule of Evidence 408, has led to an increasing willingness on the part of the federal judiciary to consider sanctions motions that rely on confidential information. Finally, Part V considers alternative means of resolving this conflict, and settles ultimately upon the adoption of a rule-based, limited federal mediation privilege as the most effective means of preventing the enforcement of mediation orders from developing into a burgeoning field of motion practice that thwarts the very docket management goal that led the federal courts to rely heavily on mediation in the first place. ${ }^{11}$ Such a rule would allow the district courts to monitor basic compliance with their orders referring cases to mediation, but prevent the sort of detailed inquiry into words and negotiating posture that landed Joe Francis in jail for nearly a year.

\section{Folding MEdiATION INTO THE DOCKet MANAGEMENT PROCESS}

It is ironic in retrospect that of all the alternative dispute resolution (ADR) processes the federal courts could have embraced as a docket management tool, they have overwhelmingly adopted mediation as the vehicle of choice for resolution of disputes outside the courtroom. ${ }^{12}$ With its emphasis on party autonomy and the mediator's lack of authority to compel the parties even to participate, mediation seems particularly ill-suited for incorporation into a court-mandated process that by definition entails an element of coercion. ${ }^{13}$ In particular, the widely-accepted notion that what transpires at mediation is confidential, a premise that protects the abovereferenced party autonomy and prevents coerced settlement, presents a substantial challenge to enforcing the mediation referral directive that is often incorporated into a typical case management order.

Part of the explanation for mediation's emergence as a docket management tool lies in the growing dissatisfaction with litigation as a

11 See infra Part V.

12 Nancy A. Welsh, The Thinning Vision of Self-Determination in Court-Connected Mediation: The Inevitable Price of Institutionalization?, 6 HARV. NEGOT. L. REV. 1, 21 (2001).

13 See Lucy V. Katz, Compulsory Alternative Dispute Resolution and Voluntarism: Two-Headed Monster or Two Sides of the Coin?, 1993 J. DISP. RESOL. 1, 13 (discussing pressure from court to participate in "voluntary" mediation); Stephan Landsman, $A D R$ and the Cost of Compulsion, 57 STAN. L. REV. 1593 (2005) (analyzing effect of both contractual and court compelled mediation on process). 
dispute resolution process during the 1970 s and early $1980 \mathrm{~s} .{ }^{14}$ This period coincided with the development of federal rules and statutory ADR law, beginning with the amendment of FRCP Rule 16, in 1983, to include as a case management issue "facilitating the settlement of the case." 15 The rule was amended in 1993, directing the courts to consider special procedures to assist in resolving disputes. ${ }^{16}$ At the same time mediation was coming into its own as the ADR tool of choice, judges increasingly came to see their role as that of docket managers. As part of this new perception, the judiciary developed a preference for settlement over trial, placing "their institutional authority behind settlement as the mode of disposition to be preferred."17 This disposition toward encouraging settlement was despite the fact, as documented by Professor Hensler and others, that litigants expressed a preference for more formal dispute resolution that provides an opportunity to be heard and a more "fair" forum. 18

One particularly unfortunate consequence of incorporating mediation, by inference at least, into the Rule 16 checklist was that it muddied the critical

14 See Deborah R. Hensler, ADR Research at the Crossroads, 2000 J. DISP. RESOL. 71 (discussing evolution of court-sanctioned ADR from the 1970s through the 1990s). Peter N. Thompson, Enforcing Rights Generated in Court-Connected MediationTension Between the Aspirations of a Private Facilitative Process and the Reality of Public Adversarial Justice, 19 OHIO ST. J. ON DISP. RESOL. 509, 516 (2004) ("Certainly, the rapid growth of the ADR movement was fueled in large part by a rejection of the adversariness and inflexibility of the litigation process.").

15 FED. R. CIV. P. 16(a)(5).

${ }^{16}$ Id. Note, however, that these procedures were and are only to be mandated "when authorized by statute or local rule." FED. R. CIV. P. 16(C)(9). This criterion would not be satisfied until the advent of, and drafting of rules arising out of, the CJRA and the ADR Act of 1998, discussed later in this article.

17 Judith Resnik, Mediating Preferences: Litigant Preferences for Process and Judicial Preferences for Settlement, 2002 J. DISP. RESOL. 155, 159; see also Ellen E. Deason, Procedural Rules for Complementary Systems of Litigation and MediationWorldwide, 80 NOTRE DAME L. REV. 553, 559-60 (2005) (discussing institutionalization of settlement procedures under federal rules); $c f$. Roselle L. Wissler, Court-Connected Mediation in General Civil Cases: What We Know from Empirical Research, 17 OHIO ST. J. ON DISP. RESOL. 641, 661-63 (2002) (finding that attomeys and judicial personnel held more favorable views of mediation's effect on time and cost of litigation than views held by parties themselves).

18 Deborah R. Hensler, Suppose It's Not True: Challenging Mediation Ideology, 2002 J. DISP. RESOL. 81, 82-88; Landsman, supra note 13. 
distinction between mediation and the judicial settlement conference. ${ }^{19}$ Long before the implementation of mediation as a docket management tool, the federal courts have relied on the judicial settlement conference as a means of resolving lawsuits. ${ }^{20}$ These settlement conferences differ from mediation, however, in two critical respects. First, they have always been unambiguously treated as a means of docket management, with the objective of obtaining a dismissal of the lawsuit. In contrast, mediation is not, or at least should not be, focused on settlement at the expense of principles such as client autonomy. In fact, mediation ethics standards often proscribe mediators from engaging in conduct that is driven by a desire for a high settlement rate, or attempting to market their services on the basis of settlement statistics. ${ }^{21}$

The judicial settlement conference also differed from mediation insofar as it included no confidentiality protections - the parties were across the table from the judge and from each other, and clearly nothing that was said could be kept from the court's purview. This, in turn, allowed the court to evaluate whether a party had participated in the settlement conference "in good faith": a concept that had no precedent in mediation scholarship. As will be discussed in Part III, it was this notion of good faith, metastasized from the old judicial settlement conference into the context of court-ordered mediation that led to the erosion of confidentiality in court-ordered mediation. ${ }^{22}$

Not long after the amendments to Rule 16 brought ADR, and therefore mediation, into the courts' docket management tool kit, statutory developments further propelled the adoption of ADR by the courts. Beginning with the Civil Justice Reform Act of 1990 (CJRA), ${ }^{23}$ Congress mandated that courts implement a civil justice expense and delay reduction

${ }^{19}$ See Welsh, supra note 12 , at 25 ("Court-connected mediation of non-family civil cases is developing an uncanny resemblance to the judicially-hosted settlement conference."); Thompson, supra note 14, at 517.

20 See Holly A. Streeter-Schaefer, A Look at Court Mandated Civil Mediation, 49 DRAKE L. REV. 367, 371 (2001) (discussing history of evolution from settlement conference to court-ordered mediation).

${ }^{21}$ See Model StANDARDS OF CONDUCT For MEDIATORS I(B) (2005) ("A mediator shall not undermine party self-determination by any party for reasons such as higher settlement rates...."); M.D. TENN. LOCAL R. Appendix 1(a), Guide 5(f) ("In any personal advertisement, an Arbitrator, Mediator or Evaluator shall not make any claims about his or her participation in the ADR program of the District Court other than the simple statement that the neutral is a member of the ADR panel of this Court.").

22 See infra text accompanying notes 33-61.

23 Civil Justice Reform Act of 1990, 28 U.S.C. $§ 471$ (1990). 
plan. ${ }^{24}$ This included the use of ADR processes, including mediation. Pursuant to the CJRA, the courts could direct party participation in judicial settlement conferences as part of their civil justice expense and delay reduction plan. ${ }^{25}$ Notably, Congress contemplated during the creation of the CJRA that the courts adopt procedures to protect the confidentiality of any ADR process, and not just mediation. ${ }^{26}$ Nearly a decade later, the Alternative Dispute Resolution Act of $1998^{27}$ amended and expanded upon the earlier 1988 Judicial Improvements and Access to Justice Act, ${ }^{28}$ with the stated purpose of reducing backlog through "greater efficiency in achieving settlements." 29 The ADR Act specifically referenced mediation as an ADR process, and directed the various federal courts to develop their own ADR rules. ${ }^{30}$ This direction that courts create and adopt alternative dispute resolution procedures at the local level has led to the crazy quilt of largely inconsistent guidelines that govern compulsory mediation in the federal courts. ${ }^{31}$

Thus, by the beginning of this decade the federal courts had folded mediation into their pretrial case management processes under Rule 16, and had adopted local rules of varying detail that set forth the standards by which

24 Id.

${ }^{25} I d$. at $\S 473(\mathrm{~b})(5)$.

26 Judicial Improvements Act of 1990, Pub. L. No. 101-650, § 102 (1990) (Congressional Statement of Findings).

${ }^{27}$ Alternative Dispute Resolution Act of 1998, Pub. L. 105-315 (1998) (codified at 28 U.S.C. $\S \S 651-58(2010))$.

28 Judicial Improvements and Access to Justice Act, Pub. L. No. 100-702 (1988) (codified as amended at 28 U.S.C. $\$ \S 651-58(1988)$ ).

${ }^{29}$ Alternative Dispute Resolution Act of 1998, Pub. L. 105-315, § 2(1) (1998) (codified at 28 U.S.C. $\$ \S 651-58$ (2010)); see also James J. Alfini \& Catherine G. McCabe, Mediating in the Shadow of the Courts: A Survey of the Emerging Case Law, 54 ARK. L. REV. 171, 173 (2001) ("Court-sponsored mandatory mediation programs generally are promoted and established, however, for reasons of judicial economy, with little attention given to mediation's core values.").

${ }^{30}$ Alternative Dispute Resolution Act of 1998, Pub. L. 105-315, $\S 3$ (1998) (codified at 28 U.S.C. $\S 651$ (b) (2010)).

31 The lack of uniformity created by the ADR Act was not unintentional, however. As pointed out in Gregory A. Litt, No Confidence: The Problem of Confidentiality by Local Rule in the ADR Act of 1998, 78 TEX. L. REV. 1015 (2000), and adumbrated by John Maull, ADR in the Federal Courts: Would Uniformity Be Better?, 34 DUQ. L. REV. 245 (1996), the legislative history of the Act suggested that Congress wished to reserve to the courts the discretion to craft their own ADR programs based on their varying caseloads. 
courts would gauge compliance with referral orders. At the same time, no court had expressly abrogated the principle of mediation confidentiality, and in fact many courts adopted rules protecting the confidentiality of what was said or done at mediation. ${ }^{32}$ It was the subsequent development of a body of law that both exercised control over the parties' participation in mediation, and purported to recognize (or at least not expressly eliminate) mediation confidentiality, that created the space within which parties could seek sanctions for noncompliance with a mediation referral order, but would risk being sanctioned themselves if the contents of the motion violated local mediation confidentiality rules.

\section{A. The Development of the Notion of Mediation Good Faith}

As discussed above, the source of the courts' perception of a right to regulate what transpires at mediation derives from FRCP Rule 16(c)(2)(I), which allows a court, at a pretrial conference, to consider "settling the case and using special procedures to assist in resolving the dispute when authorized by statute or local rule." 33 Pursuant to the mandate of the ADR Act of 1998, all district courts now incorporate ADR procedures into their local rules, and have the authority to impose special procedures, usually including mediation, as a means of controlling their dockets. ${ }^{34}$ Many courts and commentators have concluded that this authority to mandate participation in ADR was not, however, derived solely from Rule $16 .{ }^{35}$ Rather, beginning with the case of G. Heileman Brewing Co. v. Joseph Oat Corp. ${ }^{36}$ courts perceived their ability to sanction noncompliance with an order related to settlement procedures as deriving not from the language of

32 See infra Part II.B, and Appendix.

33 FED. R. CIV. P. 16(c)(2)(I).

${ }^{34}$ See infra Appendix for rules of the various U.S. district courts adopted pursuant to the ADR Act of 1998, or as part of a pilot program created under the earlier CJRA.

35 Amy M. Pugh \& Richard A. Bales, The Inherent Power of the Federal Courts to Compel Participation in Nonbinding Forms of Alternative Dispute Resolution, 42 DUQ. L. ReV. 1, 2, 10 (2003); Maureen A. Weston, Checks on Participant Conduct in Compulsory ADR: Reconciling the Tension in the Need for Good-Faith Participation, Autonomy, and Confidentiality, 76 IND. L.J. 591, 623 (2001); see also Robert J. Pushaw Jr., The Inherent Powers of Federal Courts and the Structural Constitution, 86 IowA L. REV. 735 (2001) (overview of the inherent powers of the federal courts).

${ }^{36}$ G. Heileman Brewing Co., Inc. v. Joseph Oat Corp., 871 F.2d 648 (7th Cir. 1989). 
Rule 16, but from the inherent authority of the court "to preserve the efficiency, and more importantly the integrity, of the judicial process." 37

One cannot ascribe solely to Heileman and its immediate progeny, however, the notion that a court may impose a good faith standard upon one's participation in mandated mediation. In fact, the Heileman case did not deal with mediation at all. Rather, Heileman addressed the issue of whether a district judge could compel a party's attendance at a pretrial settlement conference, when that party was represented by counsel. Judge Kanne's opinion expressly stated that a court could not "coerce settlement," and attempted to draw a fine distinction between compelling attendance and compelling more than the most perfunctory participation. ${ }^{38}$ Perhaps anticipating the mischief to come, Judge Posner in his dissent was explicit in reasoning that there is no authority for a court to compel negotiation in good faith, and concluded that the magistrate judge overstepped his authority by directing not merely the appearance of a corporate representative at a settlement conference, but a representative with "full settlement authority." 39 Judge Manion's dissent speaks further to the hollowness of the distinction articulated by the majority, between attendance and good faith participation, noting that requiring the former without the latter meant a court would "waste litigants" time doing what their attorneys could have done (and were hired to do)."40

The recognition by the Heileman court of a district judge's inherent authority to compel a party's attendance at a pretrial settlement conference dovetailed with the courts' longstanding, rule-based authority to sanction a party who failed to participate in a settlement conference in good faith. This authority, once again, derived directly from Rule 16 , which provides that a trial court could issue a sanctions order if a party or its attorney "is substantially unprepared to participate-or does not participate in good faith-in the conference." 41 Since the advent of this rule decades ago, courts have sanctioned parties who appeared at settlement conferences unprepared to negotiate, or lacking the authority to negotiate in good faith. ${ }^{42}$

${ }^{37} I d$. at 652 .

38 Id. at 653.

${ }^{39} \mathrm{Id}$. at 658 (Posner, J., dissenting).

${ }^{40}$ Id. at 669 (Manion, J., dissenting).

${ }^{41}$ FED. R. CIV. P. 16(f)(1)(B); see also supra text accompanying notes 15-17.

42 See, e.g., In re Novak, 932 F.2d 1397, 1409 (11th Cir. 1991) (affirming criminal contempt order based in part on nonparty insurer's refusal to appear at pretrial settlement conference); Francis v. Women's Obstetrics and Gynecology Group, P.C., 144 F.R.D. 646, 648-49 (W.D.N.Y. 1992) (sanctioning attorneys under Rule 16(f) for appearing at 


\section{IS IT TIME FOR A FEDERAL MEDIATION EXCLUSIONARY RULE?}

Examples of courts sanctioning parties for their failure to participate in good faith at settlement conferences began to appear in the mid-1980s, and increased substantially in the years that followed. ${ }^{43}$ Almost without exception, the sanctions appear always to have been directed at a recalcitrant defendant (rather than a plaintiff) whose conduct thwarted a judicial attempt to facilitate settlement. ${ }^{44}$ Typically, these sanctions orders related to similar patterns of conduct. For instance, a district judge may have ordered that a representative of a liability carrier attend the settlement conference, and the failure to send such a representative, or a representative with adequate authority to settle the case, resulted in the imposition of sanctions. ${ }^{45}$ Or, even more commonly, courts have sanctioned parties and their attorneys for failing to show up at all. ${ }^{46}$ Courts have also sanctioned parties for wasting the

settlement conference unprepared to discuss issues related to insurance coverage) Dvorak v. Shibata, 123 F.R.D. 608, 610-11 (D.Neb. 1988) (awarding sanctions to plaintiff for defense attorneys' substantial unpreparedness to participate in settlement conference); cf. Simpson v. City of Philadelphia, 660 F. Supp. 951, 952 (E.D. Pa. 1987) (imposing sanctions on attorney for being substantially unprepared to discuss issues in case at pretrial conference); In re Philbert, 340 B.R. 886, 890-91 (Bkrtcy. N.D. Ind. 2006) (relying alternatively on Rule 16 or court's inherent powers to sanction counsel for failure to appear at contested hearing on motion for relief from automatic stay).

43 See, e.g., PHLO Corp. v. Stevens, No. 00CIV.3619, 2001 WL 1398652 (S.D.N.Y. Nov. 9, 2001); Mordechai v. St. Luke's-Roosevelt Hosp. Ctr., No. 99CIV3000RWSTHK, 2001 WL 699062 (S.D.N.Y. June 20, 2001); Hughes v. The Lillian Goldman Family, LLC, No. 00CIV.2388, 2000 WL 1228996 (S.D.N.Y. Aug. 30, 2000); Carol L. Izumi \& Homer C. La Rue, Prohibiting "Good Faith" Reports Under the Uniform Mediation Act: Keeping the Adjudication Camel Out of the Mediation Tent, 2003 J. DisP. RESOL. 67, 75 (detailing growth in good faith motion practice after 1990); Landsman, supra note 13, at 1606-07 (detailing growth in good faith motion practice after 1990).

${ }^{44}$ See, e.g., Guillory v. Domtar Indus. Inc., 95 F.3d 1320, 1334-35 (5th Cir. 1996) (holding that defendants' refusal to make a settlement offer with realistic potential of being accepted by the plaintiff demonstrated a lack of good faith such that the imposition of sanctions was well within the court's discretion); Dvorak, 123 F.R.D. at 611 (imposing sanctions on defendant who was substantially unprepared to participate in the settlement conference). But see Those Certain Underwriters at Lloyd's, London v. GMC Land Servs., Inc., No. 06-60325-CIV, 2007 WL 3306964 (S.D.Fla. Nov. 6, 2007) (defendant sought sanctions against plaintiff for failing to attend mediation with corporate representative).

45 See, e.g., Lockhart v. Patel, 115 F.R.D. 44, 45 (E.D. Ky. 1987) (striking pleadings of defendant whose insurance carrier sent "flunky" from home office instead of representative with adequate settlement authority).

${ }^{46}$ See, e.g., Rogers v. City of Warren, 302 F.App'x 371, 379 (6th Cir. 2008) (affirming sanction of dismissal for failure to appear at settlement conference and status conference); Frontier Ins. Co. v. Blaty, 454 F.3d 590, 604 (6th Cir. 2006) (affirming 
court's time by scheduling a settlement conference and then arriving with little or no settlement authority and, in some instances, with the stated intent of taking the case to trial. ${ }^{47}$

Thus, by the late 1990s it was well-established that courts could compel represented parties to appear at judicial settlement conferences, and could sanction them if they arrived unprepared to negotiate in what the court perceived to be good faith. On the heels of this development, as discussed above, Congress mandated through the ADR Act of 1998 that the district courts develop local ADR rules as a means of controlling their dockets. ${ }^{48}$ It was perhaps inevitable, then, that at some point the courts would extend their authority to adjudge a litigant's good faith participation in a settlement conference to include mediations ordered pursuant to local rule. In so doing, the federal courts have arguably created a new sort of ADR vehicle, not quite mediation but not a settlement conference either, the conduct of which is subject to the watchful eye of the ordering court.

The courts have proven remarkably facile in constructing this new power to regulate mediation out of the rule-based, or inherent, authority they wielded at the settlement conference. The catalyst for this expansion may well be the reasoning in Heileman, which rested on a court's inherent power "to achieve the orderly and expeditious disposition of cases."49 If the courts have this authority by implication and Congress has explicitly directed them

default against insurance agency for failure to appear at settlement conference); Nostalgia Network, Inc. v. Rayle, 11 F. App'x 720, 721 (9th Cir. 2001) (reversing default judgment against defendant for failure to appear at settlement conference); Goldman, Antonetti, Ferraiuoli, Axtmayer \& Hertell v. Medfit Int'l., Inc., 982 F.2d 686, 693 (1st Cir. 1993) (affirming dismissal under Rule 16(f) for, inter alia, failure to appear at settlement conference).

47 See, e.g., Official Airline Guides, Inc. v. Goss, 6 F.3d 1385, 1397 (9th Cir. 1993) (affirming sanctions award for failure of party to appear with settlement authority); In re Novak, 932 F.2d at 1409 (affirming criminal contempt conviction of insurance representative who failed to appear at settlement conference); Guillory, 95 F.3d at 1335 (5th Cir. 1996) (affirming imposition of sanctions on defendant who arrived at mediation of personal injury case involving quadriplegic plaintiff with $\$ 100,000$ in settlement authority and stated desire to try case); Schwartzman, Inc. v. ACF Indus., Inc., 167 F.R.D. 694, 699-700 (D.N.M. 1996) (ordering good faith participation of United States in settlement conference, after attorney appeared with nuisance value settlement authority).

48 See ADR Hearings on 2603 and 2294, supra note 2.

${ }^{49}$ G. Heileman Brewing Co., Inc. v. Joseph Oat Corp., 871 F.2d 648, 651 (7th Cir. 1989); see also In re Atl. Pipe Corp., 304 F.3d 135, 145 (1st Cir. 2002) (holding that district judge had inherent authority, without reliance on ADR Act or local rules, to order parties to mediate). 
to implement local ADR procedures as a means of docket control, then a district judge certainly has the ability to wield this tool as a means of ensuring the parties are not flouting the court's authority behind the closed doors of the mediation conference, does he not?

A growing number of cases have resoundingly answered this question in the affirmative, either directly or by implication. For example, in Nick $v$. Morgan's Foods, Inc. ${ }^{50}$ the U.S. District Court for the Eastern District of Missouri considered a motion for sanctions brought by a sexual harassment plaintiff for, inter alia ${ }^{51}$ alleged failure to participate in good faith in a courtordered mediation. At issue was the decision by Morgan's Foods to send a representative to mediation with a maximum settlement authority of $\$ 500$, and without any ability to reconsider this position without consulting the company's general counsel by telephone. ${ }^{52}$ These facts were reported by the mediator ${ }^{53}$ to the trial court after the perhaps inevitable impasse, and the judge responded by issuing an order to show cause why Morgan's Foods should not be sanctioned. After Morgan's Foods responded by questioning whether the trial court had the authority to impose sanctions for its alleged lack of good faith, the court entered an order explaining that it maintained both express authority under Rule 16 and inherent authority to impose sanctions. ${ }^{54}$ Interestingly, the court's basis for claiming express authority was not the local rule, which required good faith participation in mediation, but rather Rule 16's provision allowing courts to order parties "to participate in pretrial proceedings, including hearings to facilitate settlement." 55 Thus, the district judge ignored the distinction between mediation and a pretrial settlement conference. ${ }^{56} \mathrm{He}$ also arguably ignored the mandate of his district

50 Nick v. Morgan's Foods, Inc., 99 F. Supp. 2d 1056 (E.D.Mo. 2000); aff'd, 270 F.3d 590, 597 (8th Cir. 2001).

51 The Morgan's Foods court also considered whether sanctions were justified based on Morgan's Foods' failure to submit a pre-mediation memorandum in accordance with the court's ADR order. Id. at 1061-62.

52 Morgan's Foods, 99 F. Supp. 2d at 1058.

53 The local rules of the Eastern District of Missouri require a mediator to report back to the judge "any willful or negligent failure to attend any ADR conference, to substantially comply with the Order Referring Case to Alternative Dispute Resolution, or otherwise participate in the ADR process in good faith." E.D. Mo. LOC. R. 16-6.05(A). The last two of these criteria were apparently implicated in the Morgan's Foods case.

${ }^{54}$ Morgan's Foods, 99 F. Supp. 2d at 1059-61.

55 Id. at 1060.

56 An earlier example of the same judicial miscategorization can be found in Francis v. Women's Obstetrics and Gynecology Group, P.C., 144 F.R.D. 646, 646 (W.D.N.Y. 1992). In this earlier Francis case, the district court considered a motion for sanctions 
court's own local rules, which purported to ensure mediation confidentiality. .7

As it turned out, Morgan's Foods was a harbinger of things to come..$^{58}$ In the years immediately following, trial courts ${ }^{59}$ increasingly considered

brought by plaintiffs in a medical malpractice action against defendants who allegedly failed to act in good faith at an extrajudicial conference held as part of a "settlement week" orchestrated by the local bar association. The parties were directed to appear pursuant to an "Order to Mediation," and to provide written statements to the mediator. Relying on the court's Rule 16(f) authority to mandate good faith participation in a pretrial conference, the district court sanctioned defense counsel for failure to provide the statement, and for arriving at mediation with an unresolved insurance coverage issue.

${ }^{57}$ E.D. Mo. LoC. R. 16-6.04(A).

58 For other examples of cases blurring the line between settlement conference and mediation, see Kerestan v. Merck \& Co. Long Term Disability Plan, No. 05 CIV. 3469 , 2008 WL 2627974 (S.D.N.Y. July 2, 2008) (order relying on cases involving both mediation and settlement conference misconduct as a basis to impose sanctions under rule 16(f) for failure to appear at a settlement conference); Regan v. Trinity Distribution Serv., Inc., 251 F.R.D. 108, 111 (S.D.N.Y. 2008) (imposing sanctions for appearing unprepared at "mediation," which apparently was actually a settlement conference attended by the judge); Those Certain Underwriters at Lloyd's, London v. GMC Land Servs., Inc., No. 06-60325-CIV (S.D. Fla. 2007) (order relying on inherent powers and Rule 16 settlement conference rule as basis to consider mediation sanctions motion).

59 Although this discussion is limited to trends in the federal courts, note that state courts do not appear immune from the urge to inquire regarding what transpired at a court-ordered mediation. See, e.g., Erickson v. Smith, 909 So.2d 1173, 1175-76 (Miss. Ct. App. 2005) (describing motion for sanctions in chancery court that described mediation settlement negotiations); Smith v. Archer, 812 N.E.2d 218, 219-20 (Ind. Ct. App. 2004) (observing that appellants had disclaimed argument for bad faith sanctions based on amount of defendant's monetary offer); Stoehr v. Yost, 765 N.E.2d 684, 687 (Ind. Ct. App. 2002) (reasoning that mediation sanctions motion required evidence of bad faith, and insurer's unwillingness to "really listen" was insufficient) (emphasis in original); Avril v. Civilmar, 605 So.2d 988, 990 (Fla. Dist. Ct. App. 1992) (quashing sanctions order based on inadequacy of offer made at mediation). But see Rawlings v. Rawlings, 200 P.3d 662, 669 n.5 (Utah Ct. App. 2008) (noting that decision not to award sanctions was "consistent with the high degree of confidentiality afforded to the mediation process."); Nadeau v. Nadeau, 957 A.2d 108, 117 (Me. 2008) (declining to consider evidence of mediation communications under Maine's version of Rule 408); In re Acceptance Ins. Co., 33 S.W.3d 443, 454-55 (Tex. App. 2000) (ruling sanctions order was void where it violated practice code's confidentiality provisions). What emerges from the foregoing cases is the conclusion that jurisdictions with express confidentiality provisions which carve out narrow and specific exceptions, such as those found in the Uniform Mediation Act, appear far less likely to consider sanctions motions that purport to describe bad faith conduct at mediation. But see Massey v. Beagle, 754 So.2d 146, 147 (Fla. Dist. Ct. App. 2000) (affirming trial judge's order denying sanctions for violating mediation confidentiality, which is statutory in Florida, where plaintiffs related in their 
sanctions motions for failure to participate in good faith in court-ordered mediation. ${ }^{60}$ In most, or perhaps all, of these instances, the motions relied for their substance on communications that would otherwise have been protected by corresponding mediation confidentiality rules. As will be explored in more detail in Part III, the courts almost never considered, or even mentioned, the arguable breach of mediation confidentiality in their analyses, focusing instead on whether the described conduct constituted a violation of their mediation referral order or local rules mandating good faith participation. ${ }^{61}$ Often, the outcome involved monetary sanctions against counsel and parties based on their ostensibly confidential mediation communications or conduct.

Although the prospect of monetary sanctions for failure to satisfy a trial judge's amorphous sense of good faith was disturbing enough to lawyers advising clients regarding their obligations at mediation, at least no one had gone to jail over the issue. That is, no one had gone to jail until 2007, when Joe Francis earned the dubious distinction of being the first federal litigant to find himself ordered to jail for egregious behavior at mediation. By way of background, this federal lawsuit commenced in 2003, in the wake of a wave of state and federal criminal charges arising out of the activities of GGW founder Joe Francis and his production team in Panama City Beach in March of that year. ${ }^{62}$ The plaintiffs included seven women who alleged they were underage when they were filmed by GGW cameramen. ${ }^{63}$ All sought compensatory damages under various statutory and common law theories of

own sanctions motion alleged "bad faith" by insurance adjuster who attempted to negotiate structured, rather than lump sum, settlement). See also Alfini and McCabe, supra note 29 (reviewing primarily state law cases dealing with mediation good faith and enforcement of mediated settlement agreements).

60 In fact, this trend predated Morgan's Foods, and appears to have begun roughly at the same time that the ADR Act of 1998 became law. See James R. Coben \& Peter N. Thompson, Disputing Irony: A Systematic Look at Litigation About Mediation, 11 HARV. NEGOT. L. REV. 43, 119 (2006) (providing empirical research that demonstrates growth in this type of motion practice). Note also that Morgan's Foods was cited in briefs in numerous other, unreported cases in which sanctions were sought for alleged mediation misconduct.

${ }^{61}$ Coben \& Thompson, supra note 60.

62 Francis's state court charges can be found in the criminal files of the cases styled State of Florida v. Joseph R. Francis, et al., Cases No. 03001036 and 03001047 , Circuit Court of Bay County, Florida. The companion federal criminal case was styled United States v. Mantra Films, Inc., No. 5:06CR78/RS (N.D. Fla. Sept. 12, 2006).

63 Complaint at 9 30, Doe v. Francis, 18 Fla. L. Weekly Fed. D 241 (N.D. Fla. Oct. $8,2003)$. 
recovery. The judge in the case, ${ }^{64}$ who was simultaneously presiding over a companion federal criminal case ${ }^{65}$ arising out of the same underlying facts, entered a case management order referring the matter to mediation. 66 Pursuant to the order, the parties scheduled mediation in Panama City Beach on March 30, 2007.

The mediation was a disaster from the outset. ${ }^{67}$ Francis arrived four hours late, wearing sweat bottoms, a t-shirt, flip-flops, and a backwards baseball cap. The mediator chose to open the mediation with two semi-joint sessions, with the plaintiffs' lawyers (but not the plaintiffs themselves) going to defendants' caucus room and making opening statements to defendant and defense counsel, and then reversing the process to allow defense counsel to address the plaintiffs, without Francis present, immediately afterward. As the plaintiffs' lawyers began their opening statement, Francis allegedly placed his feet on the conference table, soles toward opposing counsel, and purported to ignore counsel's opening statement until beginning an expletiveladen response in which Francis stated he would not pay the plaintiffs a dime, and would "bury" plaintiffs' counsel and their firms. ${ }^{68}$

Remarkably, the mediation lasted for over a day following the outburst. Shortly after the parties reached an impasse, plaintiffs served a motion for sanctions, which described in detail the events at mediation, and extensively quoted from Francis's statements. ${ }^{69}$ The motion inferentially treated the issue of mediation confidentiality as a matter of state law, characterizing Francis's threat to "bury" the lawyers as a threat of violence that would fall within an

64 Judge J. Richard Smoak was appointed to the federal bench in 2005 . He was a graduate of West Point, a civil lawyer in private practice since 1973, and a certified circuit court mediator in the state of Florida. See judicial profile at www.fjc.gov/servlet/tGetInfo?jid=3093 (last visited Feb. 24, 2010).

65 See supra note 62.

66 Francis, 18 Fla. L. Weekly Fed. D at 241 (Scheduling and Mediation Order).

${ }^{67}$ Many of the facts related to the mediation and its aftermath may be gleaned from the motions filed in the case, coupled with the court's order on a motion for disqualification brought in Pitts v. Francis, No. 5:07cv169-RS-EMT, 2008 U.S. Dist. LEXIS 93047 (N.D. Fla. Dec. 19, 2007), in which the judge attempted to rebut, at some length, allegations that he was prejudiced against Francis and effectively ordered him to settle the Doe v. Francis case.

${ }^{68} \mathrm{He}$ concluded by inviting the opposing attorneys to fellate him, which, as recounted by the plaintiffs in their sanctions motion, was "the only offer [Francis made] that day." Motion for Sanctions, for Temporary Restraining Order, and to Compel at para. 15, Francis, 18 Fla. L. Weekly Fed. D at 241.

${ }^{69}$ Doe v. Francis, 18 Fla. L. Weekly Fed. D 241, 241 (N.D. Fla. Oct. 8, 2003). 


\section{IS IT TIME FOR A FEDERAL MEDIATION EXCLUSIONARY RULE?}

exception to the Florida statutory mediation privilege. ${ }^{70}$ The judge took the position that there was no privilege, however, and at oral argument on the sanctions motion, the day after the impasse, set a contempt hearing for the following week.

The contempt hearing did not go well for Francis. After hearing evidence suggesting that Francis had threatened violence at the mediation, the district judge held Francis in indirect civil contempt pursuant to the court's powers under Rule 16, and ordered coercive incarceration as a sanction. ${ }^{71} \mathrm{He}$ then suspended the order, moments before Francis was to be taken into custody, to give Francis an opportunity to mediate in good faith over the following weekend. The judge's order specifically dictated how Francis should behave, and even what he should wear, at the purgative negotiation. ${ }^{72}$ Mediation took place the next day, with the court receiving regular updates from the mediator regarding the progress of the negotiations. ${ }^{73}$ Late that afternoon the attorneys for the two sides appeared in person at the judge's home, just minutes before the expiration of the suspension of the contempt order, and reported that a settlement offer had been extended, but the plaintiffs required an additional session the following week to determine whether they could apportion the lump sum among themselves. ${ }^{74}$ Based on this representation, the court lifted the contempt order. ${ }^{75}$

When the day of the follow-up mediation arrived, three days later, the plaintiffs were able to reach an agreement among themselves regarding apportionment, only to encounter additional conditions from the defendants regarding payment over an extended period of time. ${ }^{76}$ The plaintiffs moved again for sanctions, and the judge reimposed his contempt order and directed that Francis be taken into custody. ${ }^{77}$ Shortly after he surrendered himself,

70 FLA. STAT. ANN. $§ 44.405(4)(a)(2)$ (West 2010).

71 Francis at 1-2, 18 Fla. L. Weekly Fed. D at 241, Civil Minutes-General.

72 Id. at 2.

${ }^{73}$ See Francis, 18 Fla. L. Weekly Fed. D at 241 (Order that Francis surrender to custody of U.S. Marshal). Notably, and in contrast to some other jurisdictions, the local rules for the Northern District of Florida make no allowance for such reports from the mediator to the judge.

74 The author of this article was one of the attorneys present, and has firsthand knowledge of what transpired.

$75 \mathrm{Id}$.

${ }^{76}$ Francis, 18 Fla. L. Weekly Fed. D at 241, Civil Minutes-General at 1.

${ }^{77}$ Id. at 2. 
Francis settled the case from his jail cell, ${ }^{78}$ only to be incarcerated for nearly a year thereafter for issues that arose in the course of his contempt detainment. ${ }^{79}$

Doe v. Francis may serve as an extreme example of what might go wrong for a recalcitrant participant in court-ordered mediation, but it would be incorrect to characterize the outcome as aberrational. Rather, Francis relied on an established line of authority flowing from Heileman through the court's sanctions order in Morgan's Foods, ${ }^{80}$ all of which gave the federal courts the right to monitor good faith compliance with orders to mediate, and concomitantly, the right to inquire regarding what was said at mediation. Thus, one might surmise that the federal courts do not recognize any protection of mediation confidentiality. As will be shown below, this conclusion would be incorrect, and there is a large body of authority that purports to exclude the sort of evidence that landed poor Francis in jail.

\section{B. Protecting Mediation Confidentiality Under the Current Federal Rules}

Ironically, at the same time the federal courts were taking a more active role in managing behaviors and outcomes in court-ordered mediations, they ostensibly engaged in measures designed to protect the confidentiality of

78 A photograph of Francis signing the settlement agreement in his jail cell, along with numerous other source documents related to the lawsuit and mediation, can be found at the website on which Francis tells his version of what transpired, www.meetjoefrancis.com. The author takes no position regarding the veracity of the account on the web page.

${ }^{79}$ Specifically, Francis was charged with bringing contraband, in the form of cash and prescription medications, into the jail with him. These additional felony charges led to the revocation of his bond in the state criminal case arising out of the same facts as the federal civil case. Almost simultaneously, Francis was charged in the U.S. District Court for the District of Nevada with federal income tax evasion, and he elected to be transferred to Nevada for incarceration pending trial. Although the federal judge indicated a willingness to allow release on bond, the Florida state court judge was not so willing, and bonding out of jail in Nevada would have led only to another trip across country to resume his jail time in Florida. Thus, Francis remained in jail in Nevada. With the resolution of the Florida criminal charges through a plea agreement entered on March 13, 2008, Francis was released from jail after approximately ten months in custody. The federal tax evasion charges were resolved by plea agreement in September, 2009.

${ }^{80}$ The Morgan's Foods case was cited as authority in support of plaintiffs' motion for sanctions. Supplemental Memorandum of Law Regarding Sanctions Under Rule 16, Federal Rules of Civil Procedure at 2, Doe v. Francis, 18 Fla. L. Weekly Fed. D 241, 241 (N.D. Fla. Oct. 8, 2003). 
those proceedings. These protections manifested themselves not only in the local rules developed by the various district courts, but also in the decisions of the courts on motions for sanctions brought by unhappy participants in mandatory mediation. Perhaps unsurprisingly, the fruits of this uncoordinated effort to address the issue of mediation privilege have been an inconsistent and sometimes contradictory array of approaches, with a privilege that appears robust in one jurisdiction but effaces into nonexistence in the next.

Such an outcome was largely a consequence of the ADR Act's district court-based approach to crafting ADR rules. Although the Act appeared to contemplate, and indeed invite, ${ }^{81}$ the creation of a rules-based uniform mediation privilege at a later date, it directed as a short-term protection that the district courts craft rules to "provide for the confidentiality of the alternative dispute resolution processes and to prohibit disclosure of confidential dispute resolution communications." 82 As discussed below, in the decade following the enactment of the ADR Act the various district courts have responded to this mandate with a spectrum of devices that go from expressly protecting mediation confidentiality to ignoring the issue altogether. ${ }^{83}$ Some courts have complemented a rule-based solution by recognizing a common law mediation privilege for policy-based reasons, ${ }^{84}$ even as other districts have found these same considerations insufficiently compelling to support such a move. ${ }^{85}$ Still others have drawn a distinction based on Erie v. Tompkins, ${ }^{86}$ and treated the question of mediation confidentiality in diversity cases as a matter governed by state law. ${ }^{87}$ Thus, the existence, source, and application of mediation confidentiality comprises a crazy, lacunae-pocked quilt among the various districts and circuits that comprise the federal judicial branch, providing no predictability to

81 At the same time, Congress stopped short of including a mediation confidentiality provision in the ADR Act. This is noteworthy because, in other contexts, Congress has expressly provided for the confidentiality of court-annexed ADR processes. See, e.g., 5 U.S.C. $\$ 574$ (2010) (setting forth confidentiality protections and exceptions under Administrative ADR Act).

8228 U.S.C. $\$ 652$ (d) (2010).

${ }^{83}$ See infra text accompanying notes 89-110.

${ }^{84}$ See infra text accompanying notes 121-29.

85 See infra note 130.

86 Erie R.R. Co. v. Tompkins, 304 U.S. 64, 78 (1938).

${ }^{87}$ See infra Part II.B.3. 
participants in court-mandated mediation, and threatening the values embodied in what is commonly recognized as the mediation process. ${ }^{88}$

\section{Rules-Based Approaches to Mediation Confidentiality}

As discussed previously in this article, the ADR Act of 1998 mandated that federal district courts create local rules directed to the creation of alternative dispute resolution processes. ${ }^{89}$ In response to this direction, a patchwork of largely inconsistent rules has emerged among the ninety-four federal district courts. ${ }^{90}$ This lack of consistency, both internally within each district court's rules and among the various district courts, makes the ADR confidentiality regime in federal court a minefield for lawyers and their clients. $^{91}$

The approaches of the various district courts to the issues of confidentiality and good faith take many forms. A threshold question is one of nomenclature: several district courts simply do not call their ADR process "mediation," referring instead to generic ADR processes such as "settlement conferences" that are conducted by a third-party neutral. ${ }^{92}$ One advantage of this approach is that it avoids the confusion inherent in calling something "mediation," which implies confidentiality, while at the same time imposing good faith obligations on the parties and reporting requirements on the neutral. Settlement conferences have never carried with them any notion of confidentiality, and so it seems less likely that a proceeding so named will lead to a surprise sanctions motion. At the same time, a settlement conference entails an element of at least implicit compulsion that is supposedly absent in mediation, and therefore increases the likelihood of an agreement that is not entirely voluntary because of the threat of sanctions and

88 The potential for this situation was recognized not long after the passage of the ADR Act. For a particularly prescient treatment of the issue, see Litt, supra note 31 , at 1028-29.

8928 U.S.C. $\$ 651$ (b) (2010); see also supra text accompanying notes 27-31.

90 A complete appendix charting the defining characteristics of the ADR programs of the ninety-four U.S. district courts, particularly as they pertain to confidentiality, duties of good faith, and reporting requirements, follows at the conclusion of this article.

${ }^{91}$ In addition, the lack of uniformity creates issues for litigants with cases in multiple jurisdictions, raising the issue of whether a district judge in one jurisdiction must or should apply the local confidentiality rule of the jurisdiction where the mediation took place. See Litt, supra note 31, at 1032.

92 See, e.g., D. WYO. R. 16.3 (referring to procedure bearing all indicia of mediation as "settlement conference"); C.D. CAL. R. 16-15.4 (referring to "settlement proceedings" moderated by an "Attorney Settlement Officer"). 
the role of the judge, who may be the same person who tries the case, ${ }^{93}$ as the neutral.

Another variation among courts that have incorporated mandatory mediation programs in their local rules ${ }^{94}$ pertains to the source and scope of the confidentiality they afford. Some, rather than drafting their own confidentiality rules, have simply incorporated the mediation privilege of their states. ${ }^{95}$ Others prevent the admission of evidence of statements made at mediation in a subsequent trial, leaving open the possibility that a litigant might use such evidence for some other purpose, such as a sanctions motion or motion to enforce a mediation settlement agreement. ${ }^{96}$ However, the majority of district courts that have engrafted confidentiality protections into their local ADR rules have provided broad protections that encompass not only trial, but any subsequent proceeding. ${ }^{97}$

The tension in this confidentiality regime lies in the fact that most of the same courts whose rules purport to protect statements and conduct at mediation also impose rules-based good faith standards upon the participants. The extent to which these two facets of their ADR programs, confidentiality and a duty of good faith, can be harmonized turns to some degree on the level of specificity with which the rules articulate what constitutes "good faith." Many courts provide no explanation at all,98 or state simply that a

${ }^{93}$ Many districts address this concern by having a magistrate judge or other judicial officer preside at the settlement conference, instead of the trial judge. See, e.g., S.D. CAL. CIV. R. 16.3(c) (disqualifying judicial officer who presides at settlement conference from trying case); D. UTAH CIV. R. 16-2(j)(1), ADR Plan § 6(i)(2)(c) (providing for report of violations of $A D R$ program rules to compliance judge).

94 A significant number of district courts do not have mandatory mediation programs as part of their local rules, including the District of New Mexico, the Eastern District of California, and the district courts of Maine, New Hampshire, Massachusetts, and Connecticut, among others.

95 See, e.g., S.D. FLA. R. 16.2(G)(2); N.D. IND. R. 16.6(c). Note also that some courts treat the issue as one of state law only where jurisdiction is based on diversity. See infra Part II(B)(3).

96 See, e.g., D. NEB. GEN. R. 1.2(h), Mediation Plan R. 4(e).

97 See, e.g., D. UTAH CIV. R. 16-2(g), ADR Plan § 3; D. D.C. R. 84.9; D. KAN. R. 16.3(i); W.D. TEX. R. CV-88(i).

98 See, e.g., S.D. OHIO CIV. R. 16.3(e)(4) (imposing obligation to attend mediation in good faith); D. HAW. R. 88.1(f) ("[the] [p]arties shall meaningfully participate in any mediation submitted under this rule."); S.D. ALA. R. 16.6 ("A judge of the court may order parties to participate in good faith [in ADR] procedures...."); W.D.N.Y. PROPOSED R. 16.2-1(1), available at http://www.nywd.uscourts.gov/document/ProposedLR.1-1-08.pdf ("Parties and counsel shall participate in good faith, without time constraints, and put forth their best efforts toward settlement."). 
party has an obligation to participate meaningfully in the mediation process. ${ }^{99}$ The fact that these same courts often require a mediator to report back to the judge regarding whether this amorphous standard was satisfied ${ }^{100}$ implies that, even here, reconciling mediation confidentiality and a duty of good faith is problematic at best. 101

The most glaring inconsistency between guaranteeing confidentiality and monitoring good faith lies in those rules that purport to define good faith specifically. For instance, a significant number of district courts require litigants to submit written memoranda to the mediator in advance of a mediation session. ${ }^{102}$ If the same court provides that statements in mediation are confidential, may the mediator report a party's failure to submit such a memorandum? ${ }^{103}$ What about a memorandum that contains a perfunctory analysis, or what the mediator later concludes was a material misstatement that went beyond "puffing?" It is also common for courts with mandatory mediation rules to insist that a party representative appear with "full authority to settle. ..."'104 This, in turn, may be defined in detail under the rules, ${ }^{105}$ or left open to the understanding of the parties, the mediator, or ultimately the trial judge. ${ }^{106}$ Regardless, it is manifest that one cannot articulate a basis for sanctions without stating what was communicated at mediation regarding a party representative's settlement authority, which in turn seems inconsistent with preserving confidentiality.

99 See, e.g., D. HAW. R. 88.1(f); D.N.J. CIV. R. App. Q(III).

100 See, e.g., D. HAW R. 88.1(h); S.D. OHIO CIV. R. (FAQ "What to Expect from

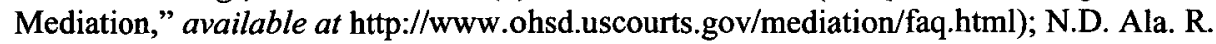
16.1, ADR Plan R. IV(B)(9)(g); W.D.N.Y. PROPOSED R. 16.2-1(n)(4)(B).

101 One pair of authors has referred to this tension between mediation's ostensible confidentiality and the duty to report back to the court regarding perceived breaches of good faith as a case of "process dissonance." See Izumi \& La Rue, supra note 43, at 68.

102 See, e.g., D. WYO. R. 16.3(c)(2)(i); N.D. GA. R. 16.7(H); S.D.N.Y. R. 83.12(i); E.D. PA. R. 53.3, Court-Annexed Mediation Protocol R. 17, available at http://www.paed.uscourts.gov/documents/locrules/civil/mediation/medpr533.pdf; S.D. OHIO CIV. R. (FAQ "What to Expect from Mediation," available at http://www.ohsd.uscourts.gov/mediation/faq.html).

${ }^{103}$ Apparently so. See Nick v. Morgan's Foods, Inc., 270 F.3d 590, 596-97 (8th Cir. 2001) (sanctioning a party for, inter alia, failure to submit a pre-mediation memorandum).

104 See, e.g., D. Miss. UNIF. R. 83.7(G)(2).

${ }^{105}$ See, e.g., D. MONT. R. 16.6(b)(4)(a); N.D. GA. R. 16.7(I)(1).

106 See generally, S.D. FLA. R. 16.2(E) (requiring attendance by representative "with full authority to negotiate a settlement," without further definition or explanation). 
Any notion of mediation privilege or confidentiality founders completely where district courts have imposed specific communications obligations on the participants and a duty to comply in good faith. For instance, the U.S. District Court for the Northern District of Georgia provides a list of questions regarding the case that a party or attorney must be prepared to answer for the mediator. What if the attorney demurs? ${ }^{107}$ The District of Nebraska goes further, requiring broad communications by the parties and allowing extensive communication between the mediator and the judge, while simultaneously purporting to protect mediation confidentiality. 108

What has emerged in the last decade, in response to the mandate of the ADR Act, has been the adoption of ninety-four different versions of an alternative dispute resolution program. Some have dealt with mediation specifically, while others have not. ${ }^{109}$ Some create an expectation of confidentiality, even while imposing a duty of good faith and an obligation for the mediator to provide specific information to the court regarding what transpired at mediation. ${ }^{110}$ For the most part the district court ADR regimes are inconsistent with each other, and often cannot be harmonized with the local state law addressing mediation confidentiality. As a means of protecting mediation confidentiality they generally have failed, undermining the mediation process as a result.

In light of this incongruity between rules that, on the one hand, allow a district judge to evaluate what transpired at mediation, while on the other hand ostensibly protecting the confidentiality of the mediation process, it is perhaps unsurprising that both sides in the GGW mediation proceeded from a faulty premise as they argued the merits of the sanctions motion. A review of the motion itself, as well as the evidence presented at the hearing, demonstrates that counsel on both sides viewed the issue of confidentiality as governed by Florida law. ${ }^{111}$ Thus, because Florida recognizes an exception to

107 See, e.g., N.D. GA. R. 16.7(H). The district court's rules provide a twist, however, insofar as the confidentiality provision only allows an exception if the district judge asks for a report on the proceedings. N.D. GA. R. 16.7(I)(5). Whether a party or mediator runs afoul of this protection by filing or providing an affidavit in support of a sanctions motion is not clearly addressed by the rule.

108 See, e.g., D. NEB. GEN. R. 1.2(h), Mediation Plan R. 4(G) (directing that mediator report to court "any actions or omissions by any of the [parties] which, in the opinion of the mediator, may violate the terms of the Mediation Reference Order or this Plan.").

109 See supra note 94.

110 See supra note 100.

111 Defendants Memorandum of Law in Opposition to Plaintiff's Motion for Sanctions, Temporary Restraining Order, and to Compel [Defendant's Memorandum], 
mediation confidentiality for threats of violence, 112 the issue framed by the parties was whether Francis's threat to "bury" plaintiffs' counsel constituted more than a figure of speech, ${ }^{113}$ and could be construed in context as a physical threat against the attorneys in the room. This led the plaintiffs to present evidence at the contempt hearing suggesting Francis's demeanor indicated that he meant for his words to be construed as a threat of violence, and that physical blows appeared imminent as the words were spoken. ${ }^{114}$ It was only on the final day of proceedings that the plaintiffs first raised the argument that the judge was empowered by Rule 16 to impose sanctions, and it was on this basis, and not the Florida "threat of violence" exception, that the judge ultimately based his contempt citation. ${ }^{115}$

Moreover, the confusion arising out of the disparate treatment of mediation privilege among the federal courts has created a potential source of liability for parties who seek to rely upon mediation communications for some purpose other than sanctions. For instance, In re Anonymous ${ }^{116}$ presented the question of whether an attorney could be sanctioned for disclosing confidential mediation communications in the course of arbitrating a fee dispute. Under the local rules governing ADR, information disclosed at mediation was to be kept strictly confidential. 117 Notwithstanding, an attorney who participated in a court-ordered mediation revealed information related to the mediation in a fee arbitration proceeding, ostensibly in response to previous disclosures by his former client, and all found

Doe v. Francis, 18 Fla. L. Weekly Fed. D 241, 241 (N.D. Fla. Oct. 8, 2003). Memorandum of Law in Support of Plaintiff's Motion for Sanctions, for Protective Order, and to Compel [Plaintiff's Memorandum], Francis, 18 Fla. L. Weekly Fed. D at 241.

112 There is very little reported case law as to what constitutes a "threat of violence," although this exception is recognized in most jurisdictions and under the Uniform Mediation Act. See, e.g., Fla. STAT. § 44.405(4)(a)(2) (2010); UnIF. Mediation Act $\S 6(\mathrm{a})(3)(2001)$.

113 On this point, the author unsuccessfully argued to the judge that the threat could not be taken literally, because Francis was not "holding a shovel" when he made the statement. Defendant's Memorandum at 8, Francis, 18 Fla. L. Weekly Fed. D at 241. Humor is always a risky tactic with an angry federal judge, and it did not carry the day here.

114 Transcript of Evidentiary Hearing Held on March 30, 2007 Before Judge Richard Smoak, at 12-13, Francis, 18 Fla. L. Weekly Fed. D at 241.

115 Supplemental Memorandum Regarding Sanctions Under Rule 16, Federal Rules of Civil Procedure, Francis, 18 Fla. L. Weekly Fed. D at 241.

116 In re Anonymous, 283 F.3d 627 (4th Cir. 2002).

117 Id. at 632 (quoting 4TH CIR. R. 33). 
themselves hailed before the circuit's Standing Panel on Attorney Discipline. Although the appellate court determined the disclosures violated the local confidentiality rule, it elected not to sanction the parties because the violations were neither intentional nor in bad faith, and the harm was minimal. ${ }^{18}$ By analogy, one might expect that the mediation confidentiality conferred by local rule or by common law would prevent sanctions motions that disclose communications which are clearly within the rule of confidentiality. In most, but not all, cases the confidentiality rule does not recognize an exception for motions for sanctions based on an alleged failure to mediate in good faith. ${ }^{119}$ As with the attorney in In re Anonymous, however, litigants increasingly have sought sanctions with motions that rely upon confidential mediation communications, sometimes obtaining an order awarding sanctions and sometimes being sanctioned themselves for their disclosures. ${ }^{120}$ The confusion lies in the courts' inconsistent treatment of the express protections they have conferred, beginning with the dissonance between attempts to define a mediation privilege through the common law, by statute, or in accordance with local state law.

\section{Common Law Recognition of a Federal Mediation Privilege}

Numerous federal courts have considered the recognition ' of a federal, common law mediation privilege, but the results are impossible to reconcile. While some district courts apply a generic analysis to the issue of whether to recognize a mediation privilege, ${ }^{121}$ others look to the interplay between their own local rules and the ADR Act's guidance on mediation confidentiality, ${ }^{122}$ often reaching contradictory results. Still other analyses have turned on the issue of whether the question presented is one of state or federal law, ${ }^{123}$ raising the possibility of mediation privilege extending to some but not all evidence in the same lawsuit. The results are, in sum, varied and inconsistent.

Some federal courts have simply recognized the existence of a common law mediation privilege. Among those recognizing the existence of a

$118 \mathrm{Id}$. at $635-36$.

119 Those that do recognize such an exception include D. NEB. GEN. R. 1.2(h), Mediation Plan R. 4(g); N.D.N.Y. R. 83.11-5(d)(3); and W.D.N.Y. PROPOSED R. 16.2$1(\mathrm{n})(4)(\mathrm{B})$.

${ }^{120}$ See infra text accompanying note 190 ; Coben \& Thompson, supra note 60 , at 122-23.

121 See infra text accompanying notes 124-28.

122 See infra text accompanying notes 132-36.

123 See infra text accompanying notes 143-60. 
privilege, most analyzed the question by way of Federal Rule of Evidence 501 , which allows the creation or recognition of a privilege as a matter of federal common law where warranted "in the light of reason and experience." 124 For instance, in the case In re $R D M,{ }^{125}$ the bankruptcy judge determined that a federal mediation privilege protected certain documents exchanged at two mediations. The court applied the generic rubric in Jaffee v. Redmond ${ }^{126}$ to determine whether to recognize a privilege, considering

(1) whether the asserted privilege is 'rooted in the imperative need for confidence and trust'; (2) whether the privilege would serve public ends; (3) whether the evidentiary detriment caused by the exercise of the privilege is modest; and (4) whether the denial of the federal privilege would frustrate a parallel privilege adopted by the states. ${ }^{127}$

In applying these factors to recognize a mediation privilege, the In re RDM court observed that protecting the confidentiality of mediation actually furthered the goal of docket management, insofar as a lack of such protections would inhibit parties from revealing sensitive information, therefore making settlement less likely, or leading them to refuse to participate altogether. ${ }^{128}$

At least a handful of federal courts have recognized the existence of a federal, common law mediation privilege. ${ }^{129}$ Not all agree on this point, however. ${ }^{130}$ Some, when faced with the question of whether to recognize a mediation privilege, have decided that the issue need not be decided in the case before the court. ${ }^{131}$ Still others have drawn a distinction between a rule of confidentiality, which is routinely provided in their local ADR rules, and a

124 FED. R. EVID. 501.

125 In re RDM Sports Group, Inc., 277 B.R. 415, 425-31 (Bankr. N.D. Ga. 2002).

126 Jaffee v. Redmond, 518 U.S. 1, 10-17 (1996).

${ }^{127}$ In re RDM, 277 B.R. at 427 (quoting Folb v. Motion Picture Indus. Pension \& Health Plans, 16 F. Supp. 2d 1164, 1171 (C.D. Cal. 1998)).

128 In re RDM, 277 B.R. at 427-28.

129 Sheldone v. Pa. Tpk. Comm'n., 104 F. Supp. 2d 511, 512-18 (W.D. Pa. 2000); Folb, 16 F. Supp. 2d at 1170-80; see also Alan Kirtley, The Mediation Privilege's Transition from Theory to Implementation: Designing a Mediation Privilege Standard to Protect Mediation Participants, the Process and the Public Interest, 1995 J. DISP. RESOL. 1.

130 See, e.g., Babasa v. Lenscrafters, Inc., 498 F.3d 972, 974-75 (9th Cir. 2007) (declining to reach issue of whether to recognize federal mediation privilege); Dusek $\mathrm{v}$. Mattel Inc., 141 F. App'x 586, 588 n.2 (9th Cir. 2005) (same).

131 See supra note 130. 
privilege that would protect any mediation communications from not only disclosure but discovery. These courts tend to eschew the Jaffee analysis altogether and look to the ADR Act and their own local rules to ascertain whether a mediation privilege may be implied from the local rules' confidentiality protections.

For instance, in FDIC v. White, ${ }^{132}$ the U.S. District Court for the Northern District of Texas rejected an argument by the FDIC that a mediation privilege was implied by the language in the ADR Act ${ }^{133}$ that directs that federal courts implement rules to protect mediation confidentiality. The issue before the court in White was whether to consider evidence of duress in procuring a mediated settlement agreement that the FDIC had moved to enforce; the nonmovant defendants sought to offer evidence of events at mediation that constituted duress. In concluding no mediation privilege applied, the White court drew a distinction between confidentiality, which was specifically addressed in the ADR Act, and privilege, which was not. ${ }^{134}$ The trial judge concluded that to recognize a mediation privilege "would effectively bar a party from raising wellestablished common law defenses such as fraud, duress, coercion, and mutual mistake," and observed that it was unlikely Congress intended such a "draconian result." 135 Notably, the court reached its conclusion with no mention at all of the Jaffee factors, and notwithstanding not only a local rule that ostensibly protected the confidentiality of mediation, but also provisions related to mediation confidentiality in the referring order. ${ }^{136}$

While not directly addressing the possibility of a federal common law mediation privilege, the district court in EEOC v. Northlake Foods, Inc., ${ }^{137}$ reached a seemingly contradictory result based on the same criteria. In Northlake, the EEOC sought to disclose the monetary amount set forth in a confidential mediation settlement agreement between an employer and an allegedly sexually harassed employee. The employer moved for a protective order, relying on a local rule that provided proceedings and statements at mediation were "privileged in all respects." 138 In deciding that the settlement agreement was confidential, and therefore not subject to disclosure, the

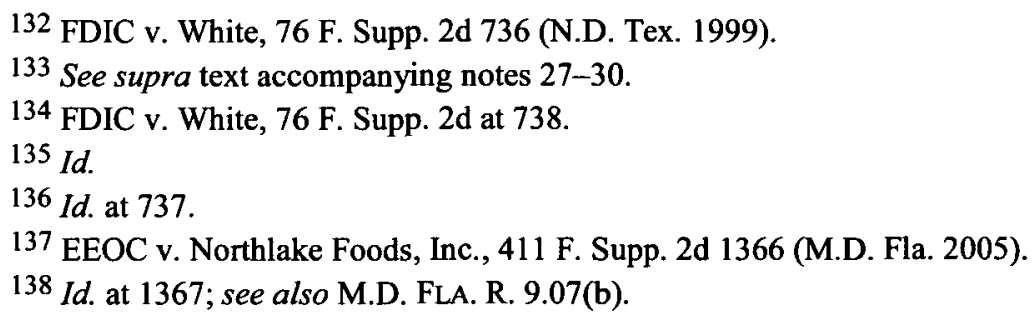


district judge relied not only on the above-referenced local rule, but also on the ADR Act's confidentiality mandate. ${ }^{139}$ Although the author would suggest that Northlake Foods was incorrectly decided in any event, insofar as it would extend a rule of mediation confidentiality or privilege to a settlement agreement rather than the mediation itself, it manifestly cannot be reconciled with White. Moreover, the reasoning in both cases bears no resemblance to that in $R D M$ or the other privilege cases, as neither mentions the Jaffee factors or a generic privilege analysis.

The potential recognition of a federal, common law mediation privilege presents at least three significant uniformity challenges. First, as illustrated above, a piecemeal Jaffee analysis by each district or circuit court to consider the issue has already produced inconsistent outcomes from district to district. Thus, one encounters the same problems of uniformity created by the patchwork of local district court rules created pursuant to the ADR Act, ${ }^{140}$ and the existence of a privilege turns upon which court referred the matter to mediation.

The second uniformity issue relates to the scope of the privilege conferred. For instance, at least one circuit has recognized the existence of a federal common law privilege that extends to settlement negotiations generally, rather than just mediation. ${ }^{141}$ There is also disparate guidance regarding the coextensiveness of the concepts of "confidentiality" and "privilege," and whether a mediation privilege applies only to matters related to the dispute, or mediation generally. ${ }^{142}$ Finally, as discussed below, there is

${ }^{139}$ Northlake, 411 F. Supp. $2 d$ at $1367-68$ n.2.

140 See supra discussion accompanying notes $81-88$.

141 See Goodyear Tire \& Rubber Co. v. Chiles Power Supply, Inc., 332 F.3d 976, 979-83 (6th Cir. 2003). This privilege has been largely rejected by other courts that have considered the issue. See, e.g., Matsushita Elec. Indus. Co., Ltd. v. Mediatek, Inc., No. C-05-3148 MMC (JCS) (N.D. Cal. Mar. 30, 2007) (order granting in part and denying in part plaintiff's motion for leave, denying motion for reconsideration, and denying motion for stay); JZ Buckingham Invs. LLC v. United States, 78 Fed. Cl. 15, 23-24 (2007); Heartland Surgical Specialty Hosp., LLC v. Midwest Div., Inc., No. 05-2164-MLBDWB (D. Kan. Apr. 27, 2007) (memorandum and order); In re Subpoena Issued to CFTC, 370 F. Supp. 2d 201, 207-12 (D. D.C. 2005). In fact, even the district courts within the Sixth Circuit have expressed reservations about the existence of such a privilege. See Grupo Condumex v. SPX Corp., 331 F. Supp. 2d 623, 629 n.3 (N.D. Ohio 2004) (expressing "misgivings" regarding settlement privilege in Goodyear, particularly in light of fact that it was a diversity case).

142 See, e.g., In re Anonymous, 283 F.3d 627, 633 (4th Cir. 2002) (rejecting argument that privilege only extended to matters related to dispute). 
a problem of uniformity arising out of the basis for the district court's jurisdiction and the nature of the issue to which the privilege might apply.

\section{State Law Privilege Rules in Federal Court}

Adding to the confusion, some courts have taken the position that in cases brought under diversity jurisdiction, the existence and scope of a mediation privilege is governed by state law. ${ }^{143}$ For example, in Mutual of Enumclaw v. Cornhusker Casualty Insurance Co., ${ }^{144}$ the district court presiding in an insurance bad faith case considered a motion for a protective order brought by an insurance company to prevent disclosure of statements made by its representative in the mediation of the underlying bodily injury action. Because the court's jurisdiction was based on diversity, and the dispute was governed by Washington law, the trial judge concluded that the Uniform Mediation Act (UMA) as adopted in Washington governed the matter of privilege. ${ }^{145}$ Just as the carrier perhaps thought it had prevailed on its argument for a protective order, given the UMA's broad privilege, the judge went on to conclude that the privilege did not apply to the statement because the underlying dispute was related to personal injury damages, rather than coverage, and the privilege only extended to statements that "pertain[ed] to the mediated dispute."146

Not all federal courts see the source of their jurisdiction as relevant to the applicability of state mediation law, however. For instance, in Olam $v$. Congress Mortgage Co., ${ }^{147}$ Judge Brazil of the Northern District of

143 For a discussion of the problem of vertical choice of law in the application of mediation privilege in federal court, see generally Ellen E. Deason, Predictable Mediation Confidentiality in the U.S. Federal System, 17 OHIO ST. J. ON DISP. RESOL. 239, 252-59 (2002).

144 Mut. of Enumclaw v. Cornhusker Cas. Ins. Co., No. CV-07-3101-FVS (E.D. Wash. Sept. 16, 2008) (order denying defendant's motion for a protective order re: mediation communications).

145 Id. at 2.

${ }^{146}$ Id. at 3 . The trial judge managed this feat by noting that a "mediation communication" is defined as "a statement, whether by [sic] oral or in a record or verbal or nonverbal, that occurs during a mediation or is made for purposes of considering, conducting, participating in, initiating, continuing, or reconvening a mediation or retaining a mediator." Id. (quoting WASH. REV. CODE $§$ 7.07.010(2)). In turn, "mediation" is defined as "a process in which a mediator facilitates communications and negotiation between parties to assist them in reaching a voluntary agreement regarding their dispute." Id. (emphasis in original) (quoting WASH. REV. CODE $§ 7.07 .010(1)$ ).

${ }^{147}$ Olam v. Cong. Mortg. Co., 68 F. Supp. 2d 1110 (N.D. Cal. 1999). 
California reasoned that because the issue presented in a motion to enforce a mediation settlement agreement was one of state law, specifically contract, Federal Rule of Evidence 501 directed that California law ${ }^{148}$ governed the issue of mediation confidentiality. This was despite the fact that the underlying claim was based, in part, on alleged violations of the federal Truth-in-Lending Act. ${ }^{149}$ Judge Brazil anticipated the very issue raised in this article, reasoning that when Congress did not include an express confidentiality protection in the ADR Act of 1998, it:

[F]oreseeably left open the substantial possibility that there would be considerable differences between the local rules different courts adopted (and that a considerable period would elapse before all 94 district courts had rules in place directed to this matter). It is not likely that Congress intended to give 94 district courts the power to vary in potentially quite different ways the proviso in Rule 501. ${ }^{150}$

Judge Brazil's observation foreshadowed the inconsistent approaches to mediation privilege that would emerge among the federal courts in the decade that followed, and he saw the recognition of state mediation privilege law as a means of providing at least a consistent methodology for predicting how courts would decide such issues. At the same time, the reasoning in Olam is limited in its application, insofar as the question presented related to the enforcement of a mediation settlement agreement, essentially a contract question. ${ }^{151}$ What of the motion to sanction a party for supposed misconduct at mediation? Although issues of contract may come into play in such situations, it seems far more likely that the movant's reasoning would rely on

148 Specifically, CAL. EVID. CODE $§ 1119$ (West 2010).

149 Olam, 68 F. Supp. $2 d$ at 1115.

150 Id. at 1123 .

151 At least one court has enforced a state mediation privilege to prevent evidence at a grand jury proceeding of communications in a prior state court-annexed mediation. In United States v. Gullo, 672 F. Supp. 99, 99 (W.D.N.Y. 1987), the defendant was charged by a federal grand jury with extortion in collecting or attempting to collect an extension of credit. The indictment allegedly relied, in part, on communications during a state dispute resolution process that was covered by a state rule of confidentiality, New York Judiciary Law $849-\mathrm{g}(6)$. Id. at 102 . The privilege was included in a state ADR process designed to resolve informally certain criminal matters. Id. at 102-03. Applying the four Jaffee factors as articulated in United States v. King, 73 F.R.D. 103, $105-09$ (E.D.N.Y. 1976), the district court found that it must recognize the privilege, although (or perhaps because) it made no difference in the outcome of the case. Gullo, 672 F. Supp. at 104; see also Joshua P. Rosenberg, Keeping the Lid on Confidentiality: Mediation Privilege and Conflict of Laws, 10 OHIO ST. J. ON DisP. RESOL. 157, 175-78 (1994) (analyzing Gullo). 
FRCP Rule 16 or the court's inherent authority to enforce its mediation order. Olam would therefore provide no refuge for the nonmovant seeking to exclude evidence of allegedly sanctionable statements or conduct, given that the rule of decision would invariably be federal.

Other courts have similarly drawn a distinction regarding the existence of a mediation or settlement privilege based not on Erie considerations, but rather the nature of the issue to which the otherwise privileged information would apply. For example, in Babasa v. Lenscrafters ${ }^{152}$ the Ninth Circuit Court of Appeals considered the basis and scope of a purported mediation privilege argued by a defendant seeking to protect a letter written by plaintiff's counsel a year earlier. If the letter was protected by a privilege, in this case the California statutory mediation privilege, ${ }^{153}$ the defendant argued that it could not serve as a basis for the district court to conclude the defendant had been put on notice that the amount in controversy was sufficient to invoke federal diversity jurisdiction and remove the case. ${ }^{154}$ The Babasa court rejected this argument, observing that under Federal Rule of Evidence 501 "privileges provided by state law apply in civil actions only 'with respect to an element of a claim or defense as to which State law supplies the rule of decision." 155 Because the question of jurisdiction was governed by federal law, the circuit court reasoned that the California mediation privilege did not bar consideration of the letter to determine when the defendant had notice of the amount in controversy. ${ }^{156}$

By similar reasoning, the district court in Folb v. Motion Picture Industry Pension \& Health Plans ${ }^{157}$ recognized and applied a federal mediation privilege in a case involving both a federal ERISA question and pendent state law claims. The plaintiff in Folb sought a letter prepared for a mediation between the defendant and a woman who had sued defendant for alleged sexual harassment. Presumably, the letter would have been relevant both to state law contractual claims and a federal whistleblower claim under ERISA. In determining that federal law controlled the issue of privilege, the Folb

152 Babasa v. Lenscrafters, Inc., 498 F.3d 972, 974 (9th Cir. 2007).

153 CAL. EVID. CODE $\S 1119$ (West 2010).

154 Babasa, 498 F.3d at 974 . For a discussion of the use of such demand letters as a basis for diversity jurisdiction, see generally Michael P. Dickey, Demand Letters and Diversity Jurisdiction, 14 COM. TR. EVID. 4 (2006).

155 Babasa, 498 F.3d at 974 (quoting FED. R. EVID. 501).

${ }^{156}$ Id. at 974-75. The Babasa court did not, however, decide whether the California mediation privilege was sufficiently broad to extend to the letter, or whether to consider the recognition of a federal mediation privilege. $I d$.

157 Folb, 16 F. Supp. 2d at 1170-80. 
court applied established precedent for the premise that where both federal and state law provided the rules of decision, because of the existence of pendent claims, federal mediation law should control. ${ }^{158}$ It then applied the Jaffee ${ }^{159}$ factors to the question of whether to recognize a federal mediation privilege, and ultimately elected to do so. 160

As discussed above, the reasoning in Olam, Babasa, and Folb suggests that a common law mediation privilege would likely apply to communications used as a basis for a post-mediation sanctions motion, although this is by no means certain. The question of whether a district court may sanction a party for mediation misconduct is surely one of federal law, whether the court is relying upon rules-based authority or its inherent authority as contemplated under Heileman. At the same time, one may fairly question whether the common law, rather than a formal rule, can prevent a district judge from enforcing a local rule of procedure, in particular a local rule providing standards of conduct for ADR. Moreover, it is difficult to imagine that a common law privilege can satisfy the requirement under Jaffee that it serve public ends, ${ }^{161}$ insofar as those ends are embodied in the rules the common law privilege would circumscribe. Thus, the most likely result of recognizing a federal common law mediation privilege is that it would fail to extend to evidence offered in support of sanctions motions arising out of mediation. As discussed below, ${ }^{162}$ the proliferation of such motions in recent years provides the strongest basis for recognizing the privilege in the first place, and so a common law privilege would fall short of its purpose.

\section{THE EXPLOSION OF “GOOD FAITH” LITIGATION}

Although not unknown prior to the enactment of the ADR Act of 1998, motion practice related to mediation since that time has expanded greatly. ${ }^{163}$ Many of these motions are based on issues unrelated to statements or conduct after the mediation has commenced, most commonly the failure of a party to

${ }^{158} \mathrm{Id}$. at $1169-70$. The court also rejected the magistrate's conclusion that comity dictated the application of state law. Id.

159 Jaffee v. Redmond, 518 U.S. 1, 10-17 (1996).

${ }^{160}$ Folb v. Motion Picture Indus. Pension \& Health Plans, 16 F. Supp. 2d 1164, 1180 (C.D. Cal. 1998).

161 Jaffee, 518 U.S. at 11.

162 See infra Part V(A).

163 See Coben \& Thompson, supra note 60 , at 48, 51-52. 


\section{IS IT TIME FOR A FEDERAL MEDIATION EXCLUSIONARY RULE?}

appear at all, ${ }^{164}$ or to appear with adequate authority to settle. ${ }^{165}$ These sorts of disputes would not be affected directly by the imposition of a mediation privilege, ${ }^{166}$ because the facts giving rise to the sanctions motion would not rely on statements made during mediation negotiations.

On the other hand, the years since the passage of the ADR Act have seen a growth in a new type of sanctions motion, based not on a party's failure to appear at all, but rather upon what is said or what transpires once the mediation begins. For instance, in Smith Wholesale Co., Inc., v. Philip Morris USA Inc., ${ }^{167}$ the district court considered a motion to vacate sanctions imposed for Philip Morris's alleged bad faith participation in a mediation. Although the judge ultimately elected to vacate the order, it is noteworthy that the basis for the motion was an assertion regarding Philip Morris's mediation negotiating posture, specifically its unwillingness to negotiate

164 See, e.g., Am. Appraisal Assoc., Inc. v. Am. Appraisals, Inc., 531 F. Supp. 2d 1353, 1355-56 (S.D. Fla. 2008); Davis v. Lane Mgmt., LLC., 524 F. Supp. 2d 1375, 1378 (S.D. Fla. 2007).

165 See, e.g., Negron v. Woodhull Hosp., 173. F. App'x 77, 79 (2d. Cir. 2006) (vacating sanctions award for failure to bring principal to mediation with full authority to settle); Nick v. Morgan's Foods, Inc., 270 F.3d 590, 597 (8th Cir. 2001) (affirming sanctions award based in part on sending representative with only $\$ 500$ in settlement authority); Scaife v. Assoc. Air Ctr., Inc., 100 F.3d 406, 412 (5th Cir. 1996) (affirming in part sanctions award against attorney for violating mediation order that directed attendance by party with full authority to settle); TR v. St. Johns County Sch. Dist., No. 3:07-cv-913-J-33MCR, 2008 U.S. Dist. LEXIS 59272 (M.D. Fla. July 28, 2008) (order denying sanctions motion based on school district representative's need to obtain consent of school board as condition of mediation settlement); Hijeck v. Menlo Logistics, Inc., No. 3-07-CV-0530-G, 2008 U.S. Dist. LEXIS 90590 (N.D. Tex. Dec. 10, 2007) (memorandum order denying motion that argued for sanctions against defendant for having human resources manager, rather than executive, appear at mediation); Those Certain Underwriters at Lloyd's, London v. GMC Land Servs., Inc., No. 06-60325-CIV, 2007 WL 3306964 (S.D. Fla. 2007) (denying sanctions motion against defendant for bringing claims representative with inadequate settlement authority to mediation).

${ }^{166}$ At the same time, sanctions motions for failure to appear, or failure to appear with adequate settlement authority, sometimes disclose detailed information regarding mediation negotiations that would otherwise be protected by local confidentiality rules. See, e.g., Performance Chevrolet, Inc. v. Mkt. Scan Info. Sys., Inc., No. CV04-244-SBLW, 2005 WL 1768650 (D. Idaho July 25, 2005) (order granting motion for sanctions for failure to send representative with full authority to settle, including detailed description of parties' opening statements at mediation, and terms of settlement offer extended by plaintiff).

167 Smith Wholesale Co., Inc. v. Philip Morris USA Inc., No. 2:03-CV-221, 2005 WL 2030655 (E.D. Tenn. Aug. 23, 2005) (memorandum opinion and order). 
regarding changes to a wholesale program. ${ }^{168}$ Neither side appears to have argued that evidence of Philip Morris's refusal to negotiate regarding this issue was confidential, given a local rule in that district barring the parties from making the mediation proceedings "known to the Presiding Judge."169

Litigants have also tested the waters by filing motions for sanctions based on the failure to make a good faith offer at mediation. Although these motions appear rarely to succeed, ${ }^{170}$ they illustrate the tension between rules supposedly conferring mediation confidentiality and the trial courts' purported inherent authority to monitor good faith compliance with a mediation referral order. ${ }^{171}$ In Nevada Partners Fund, LLC v. United States, ${ }^{172}$ plaintiffs brought a motion for sanctions because the defendant failed to make an offer at mediation in excess of what had been proposed in negotiations beforehand. The court did not impose sanctions, reasoning that although it had the inherent authority to sanction bad faith at mediation, the imposition of sanctions for failure to make an offer could be construed as coercion to settle. ${ }^{173}$ Once again, the trial judge did not mention the fact that the local rules of the Southern District of Mississippi expressly provide that parties may not communicate to the court regarding "any communication made, position taken, or opinion formed by any party or neutral in connection with mediation proceedings." 174

168 Id. at 2.

169 E.D. TENN. R. 16.4(h).

170 "Rarely" does not mean "never," however. For example, in Ferrero v. Henderson, No. C-3-00-462, 2003 WL 21796381 (S.D. Ohio June 24, 2003), the district judge "sustained" a motion for sanctions brought by an employment discrimination plaintiff who claimed her former employer acted in bad faith by refusing to make a monetary settlement offer at mediation. The motion sets forth in detail what transpired at mediation, apparently relying on an exception to the local ADR rules allowing disclosure of confidential mediation communications "in connection with possible sanctions for misconduct. ..."Id. at 5; see also S.D. OHIO Crv. R. 16.3(c)(3)(C). Even this, however, requires a determination of necessity by a judicial officer before the exception may be invoked. Id.

${ }^{171}$ For another example of a failed sanctions motion based on the failure to make a settlement offer, see Hamlett v. Gonzales, No. Civ.A. 303CV2202BHM, 2005 WL 1500819 (N.D. Tex. June 15, 2005) (memorandum opinion and order denying motion for sanctions for making alleged nominal offer, based in part on movant's violation of confidentiality protections in district court's local rules).

172 Nev. Partners Fund, LLC v. United States, No. 3:06cv379-HTW-MTP (S.D. Miss. Jan 16, 2009) (order on motion for sanctions).

$173 \mathrm{Id}$. at 1 .

174 D. Miss. UNIF. R. 83.7(K)(3). 
The most egregious among this growing body of filings are motions seeking sanctions based on a detailed recounting of supposedly confidential mediation proceedings, often in an effort to portray a negotiation strategy as "bad faith" by the opposing party. A failed sanctions effort along these lines was advanced in Damon v. UPS, ${ }^{175}$ wherein a plaintiff sought sanctions against a defendant based on the fact that the defendant "shifted ground" and "derailed the process" in a third mediation session. ${ }^{176}$ Although the motion was ultimately denied, it is difficult to imagine why this information was not treated as confidential in light of the district court's local rules. ${ }^{177}$

Perhaps the most chilling sanctions order of this new genre was entered by a magistrate judge of the Western District of New York in Fisher $v$. SmithKline Beecham Corp., ${ }^{178}$ a personal injury case arising out of the side effects of the prescription drug Paxil. Following an unsuccessful, courtordered mediation, the plaintiffs filed a motion for sanctions against defendant for failing to mediate in good faith as mandated by the local rules. ${ }^{179}$ The alleged offense? Apparently, defense counsel filed a motion for summary judgment on the day prior to the mediation, while plaintiffs' lead counsel was enroute from New Orleans to Buffalo and unable to review and analyze the motion. ${ }^{180}$ Once at the mediation, which the defendant (but not defense counsel) attended by phone, defense counsel presented a copy of the motion, and stated that there would be no offers in excess of $\$ 1,000$ until the plaintiffs explained why the motion's statute of limitations argument was incorrect. ${ }^{181}$ Roughly three weeks later the plaintiffs moved for sanctions, detailing what transpired at the mediation.

As one might expect, the defendant argued that the motion for sanctions should never have been filed, noting that the local ADR Rules rendered the mediation confidential, ${ }^{182}$ and only allowed the mediator, rather than the

175 Damon v. UPS, No. 04-CV-746S (W.D.N.Y. Jan. 9, 2009) (decision and order).

$176 \mathrm{Id}$. at 1 .

177 W.D.N.Y. Proposed R. 16.2-1(n). The rule does, however, provide an exception for the mediator to disclose whatever he perceives to be a failure to participate in good faith, which is both mandated and broadly defined under the local rules. Id. at 16.2-1(n)(4).

178 Fisher v. SmithKline Beecham Corp., No. 07-CV-0347A(F), 2008 WL 4501860 (W.D.N.Y. Sept. 29, 2008) (decision and order).

179 Id. at 2; see also W.D.N.Y. ADR PLAN $\S 5.8(\mathrm{G})$.

180 Fisher, No. 07-CV-0347A(F), at 2.

181 Id. at 3 . The fact that the mediation ended in an impasse suggests the plaintiffs' answer on this point was inadequate to cause the defendant to materially raise its offer.

182 Id.; see also W.D.N.Y. PROPOSED R. 16.2-1(n)(4)(B). 
parties, to report misconduct at the mediation. The magistrate observed that the confidentiality rule had been changed after the mediation (and, for that matter, after the sanctions motion was filed), but before his ruling, and in its current form allowed parties to report violation of the ADR Plan to the court. ${ }^{183}$ The judge also relied on 28 U.S.C. $\S 1927$, which allowed courts to impose cost sanctions on vexatious attorneys. Once the judge reasoned that the rules allowed the court to consider this evidence and to impose sanctions, he ruled that the negotiating tactic of refusing to raise the defendant's settlement offer until plaintiffs' counsel countered the defendant's statute of limitations argument constituted bad faith in violation of the local ADR rules. ${ }^{184}$ So too was the discourtesy of filing a motion for summary judgment while plaintiffs' counsel was on a flight to attend the mediation, leaving counsel unable to analyze the issues raised in advance of the mediation. ${ }^{185}$ The magistrate therefore awarded sanctions including over thirty hours of attorney time, plus fees and costs, against both defendant and its attorney. ${ }^{186}$

Among the growing mass of sanctions litigation in the federal courts related to alleged mediation misconduct, ${ }^{187}$ Fisher stands out as particularly troubling. The magistrate judge imposed sanctions for the filing of a summary judgment motion the day before the mediation, although the filing of a dispositive motion on the threshold of a court-ordered mediation is so commonplace in civil litigation that the failure to do so, particularly by a large company represented by a very big law firm, ${ }^{188}$ would have been the more surprising tactic. Apparently, the judge focused on the fact that opposing counsel was in the air at the time, and could not read it. Still, the facts in the motion could not have come as a surprise, particularly after nearly eighteen months of litigation. The nexus the judge required to turn this

183 Fisher, No. 07-CV-0347A(F), at 4.

184 Fisher v. SmithKline Beecham Corp., No. 07-CV-0347A(F), at 5, 2008 WL 4501860 (W.D.N.Y. Sept. 29, 2008).

185 Id. The magistrate judge conceded, however, that the statute of limitations had been raised as an affirmative defense at the time the case was filed, but dismissed this as "boilerplate." Id. at 6.

$186 \mathrm{Id}$. at 7.

187 See Outar v. Greno Indus., Inc., No. 03-CV-0916, at 2, 2005 WL 2387840 (N.D.N.Y. Sept. 27, 2005) (sanctioning plaintiff for violating mediation order by "[i]gnoring advice, cajoling, and common sense" in his conduct at mediation); Nick v. Morgan's Foods, Inc., 270 F.3d 590, 597 (8th Cir. 2001) (sanctioning defendant for failure to submit a mediation statement or memorandum as ordered by the court).

188 SmithKline Beecham was represented in the litigation by King \& Spalding, a national law firm based in Atlanta. See Fisher, No. 07-CV-0347A(F) at 1; see also http://www.kslaw.com/portal/server.pt (last visited Feb. 24, 2010). 
prosaic litigation tactic into a violation of the ADR rules, and then into a monetary sanction, was how the motion was used at mediation. This should never have been disclosed by the plaintiffs based on the rules as they stood at the time, and yet the judge dismissed defendant's argument on this point as impeding the court's ability to exercise its "inherent authority" that has apparently morphed to this point since Heileman. ${ }^{189}$ The end result, that a party and its attorney were sanctioned for a negotiation tactic at mediation, or perhaps for refusing to raise their offer, completely discards any pretext of mediation confidentiality, and opens the door to subjective judicial determination of the amorphous concept of good faith based on words and conduct at mediation.

At the same time that courts have cracked the door ever wider to inquire regarding whether litigants are complying in good faith with orders to mediate, judges continue to entertain and sometimes grant sanctions motions for disclosing mediation communications made confidential by local rule. These sanctions may be imposed on the very parties who commence the exchange by seeking sanctions for mediation misconduct, filing in support affidavits recounting what transpired at mediation. For example, in Williams $v$. Johanns, ${ }^{190}$ Plaintiffs' counsel in a case against the U.S.D.A. filed a "Memorandum Submission on Mediation," which provided a detailed factual explanation for counsel's contention that the defendants had not participated in mediation in good faith. The memorandum was accompanied by an affidavit, and both revealed to the court that the defendants had taken the position at mediation that they had no liability in the case. ${ }^{191}$ How this is substantively distinguishable from the motion in Fisher, supra, which discussed defendant's refusal to raise its offer at mediation, is not readily apparent.

The outcome of the two motions, however, could not have been more different. The plaintiffs' attorney in Williams not only failed to obtain the relief he sought, but was held in contempt and fined for violating a confidentiality order by revealing statements made in the course of mediation. This was despite the fact that the district court rules in Williams, just as in Fisher, included an exception to the general rule of mediation confidentiality for the reporting of violations of the court's ADR rules, which

189 See supra text accompanying notes $36-40$.

190 Williams v. Johanns, 529 F. Supp. 2d 22, 23 (D.D.C. 2008).

191 Plaintiff's Memorandum Submission on Mediation as Authorized by Magistrate Judge Facciola at para. 2, Williams, 529 F. Supp. 2d at 22. 
in turn imposed the obligation of good faith that was the subject of the Williams attorney's filing. ${ }^{192}$

Based on the foregoing, it should be apparent that the flowering of mediation sanctions motion practice over the last decade has spawned a body of often-unreported case law ${ }^{193}$ that is both inconsistent and, at times, incoherent. The perception of relative uniformity suggested by the fact that the local district court rules exhibit a high degree of similarity regarding their purported protection of mediation confidentiality is belied by the variation with which courts have enforced these rules. Although these characteristics of increased judicial management of mediation, and uncertain application of the local rules, may serve as a compelling basis to develop a uniform mediation privilege, the analysis of this issue and the characterization and scope of any such analysis must necessarily entail a review of the reasons for protecting confidentiality inherent in the mediation process.

\section{THE NEED FOR A RULE OF EXCLUSION: ANSWERING THE "WHY" QUESTION}

At this juncture, a caveat is in order: this article does not purport to provide a prescriptive regarding the source or the propriety of the district courts' supposed authority to demand that parties participate in court-ordered mediation in good faith. That has been a subject of considerable scholarly attention over the years, with plausible arguments on both sides. ${ }^{194}$ Rather,

${ }^{192}$ D.D.C. R. 84.9(c)(4), 84.10, App. A; W.D.N.Y. ADR PLAN $§ 5.8(G)$; see also infra Appendix.

193 None of the antics in Doe v. Francis were reported in the Federal Supplement. Short of district-by-district review of Case Management/Electronic Case Filing (CM/ECF). PACR filings, one would have very little way of knowing how many similar situations have arisen over the last several years. One excellent resource, however, is the Mediation Case Law Project maintained by the Hamline University School of Law. The project created a comprehensive database of cases in which mediation issues were litigated, and can be found at http://law.hamline.edu/adr/mediation-case-law-project.html (last visited Feb. 24, 2010).

194 See ABA Sec. of Disp. Resol., Resolution on Good Faith Requirements for Mediators and Mediation Advocates in Court-Mandated Mediation Programs (Aug. 7, 2004), http://www.abanet.org/dispute/draftres2.doc; STEPHEN J. WARE, PRINCIPLES OF Alternative DisPUTE Resolution 335-36 (2d ed. 2007); Wayne D. Brazil, Should Court-Sponsored ADR Survive?, 21 OHIO ST. J. ON DISP. RESOL. 241 (2006); Dr. Iur. Ulrich Boettger, Efficiency Versus Party Empowerment-Against a Good-Faith Requirement in Mandatory Mediation, 23 REV. LITIG. 1 (2004); Roger L. Carter, Oh, Ye of Little [Good] Faith: Questions, Concerns and Commentary on Efforts to Regulate 
this analysis begins with two apparently conflicting premises. First, a court has the right and the obligation to ensure that its orders are followed, at least to a point. Second, confidentiality is essential to the integrity and the effectiveness of the mediation process. ${ }^{195}$ The conflict lies in the fact that courts have dissonantly articulated adherence to the principle of mediation confidentiality and at the same time maintained their authority to control what transpires at mediation, even though this often entails judicial evaluation of communications expressly protected from disclosure. The issue, thus framed, is one that lends itself to the sort of interest focus that is familiar to any student of ADR. What interests are advanced by mediation confidentiality, and to what extent do they actually conflict with the court's interest in managing its docket by ensuring good faith compliance with its mediation orders? ${ }^{196}$ Is there a way to reconcile these interests in a way that maximizes the benefit to both the mediation process and the judiciary that has harnessed mediation to its own ends? As will be explored in more detail below, the interests protected by mediation confidentiality are sufficiently narrow and well-defined that a rule of exclusion may operate in a way that not only preserves the judicial prerogative to ensure compliance with its orders, but in fact advances the ultimate goals of docket management and cost savings.

\section{A. Policy-Based Arguments for an Exclusionary Rule}

Much of the mischief that has evolved with regard to mediation oversight in federal court may owe its origins to a misunderstanding of the purpose of mediation confidentiality. Among most commentators, the policy bases for protecting mediation communications from disclosure fall broadly into two categories. The first recognizes the importance of confidentiality as a means

Participant Conduct in Mediations, 2002 J. DisP. RESOL. 367; Kimberlee K. Kovach, New Wine Requires New Wineskins: Transforming Lawyer Ethics for Effective Representation in a Non-Adversarial Approach to Problem Solving: Mediation, 28 FordHAM URB. L.J. 935 (2001); John Lande, Using Dispute System Design Methods to Promote Good-Faith Participation in Court-Connected Mediation Programs, 50 UCLA L. REv. 69, 79-82 (2002); Landsman, supra at note 13; Edward F. Sherman, CourtMandated Alternative Dispute Resolution: What Form of Participation Should Be Required?, 46 SMU L. REV. 2079, 2085 (1993); Weston, supra note 35, at 609-18.

195 For a concise articulation of the policy arguments in support of affording legal protection to mediation confidentiality, see Deason, supra note 17, at 563-65.

196 The concept of separating positions from interests was first popularized in Roger Fisher, William L. Ury \& Bruce Patton, GetTing to Yes: Negotiating AGREEMENT WITHOUT GIVING IN (1981). 
of protecting party autonomy or, in the alternative, the voluntariness of the process and any resulting settlement. ${ }^{197}$ The notion is that by preventing disclosure, courts protect parties from being extorted into settlement by the threat that their statements may become public. ${ }^{198}$ There is broad recognition that a party whose communications or conduct may ultimately find their way onto the desk of the local district judge may have an incentive to settle that is based on the fear of sanctions rather than the merits of the case or the cost of going forward, and that settlement on this basis is not generally desirable. 199 On balance, ${ }^{200}$ the prevention of settlement coercion is seen as a beneficial effect of confidentiality. In addition, autonomy includes the premise that a

${ }^{197}$ Kirtley, supra note 129 , at 18; Litt, supra note 31 , at 1021.

198 Izumi \& La Rue, supra note 43, at 74; cf. Ellen E. Deason, The Need for Trust as a Justification for Confidentiality in Mediation: A Cross-Disciplinary Approach, 54 U. KAN. L. REV. 1387 (2006) (arguing importance of trust as basis for mediation confidentiality, because of risk of disclosing sensitive matters discussed during mediation, and importance of information sharing in reaching optimal agreement); Sherman, supra at note 194, at 2085-86 (observing that one advantage of mediation over settlement conferences is that settlement conferences involved "judge who used a combination of jaw-boning and veiled threats to move the parties toward settlement.").

199 See, e.g., Powell v. Carey Int'l, Inc., 547 F. Supp. 2d 1281, 1298 n.28 (S.D. Fla. 2008) (refusing to award sanctions against attorney who mistakenly included mediation communications in affidavit, noting that opposing counsel's motion for sanctions "causes concern as the manner in which Plaintiffs' counsel attempted to profit from defense counsel's error is tantamount to extortion.'); Doe v. Nebraska, 971 F. Supp. 1305, 1308 (D. Neb. 1997) ("Obviously the protections of the confidentiality provisions would be undermined if they could be circumvented by filing a motion for sanctions and the confidential information could later be used in the litigation in any way against either of the parties.").

200 This is not to say that confidentiality may not provide a veil for conduct that undercuts voluntariness. For instance, commentators have noted that unscrupulous mediators or mediation participants may resort to coercion or deception as means of effecting a settlement, and such conduct would arguably be protected from disclosure by confidentiality rules. See Timothy Hedeen, Coercion \& Self-Determination in CourtConnected Mediation: All Mediations Are Voluntary, but Some Are More Voluntary than Others, 26 JUST. SYS. J. 273, 279-83 (2005) These concerns are particularly acute where there is asymmetry of legal or informational resources between the parties, or where gender or socioeconomic characteristics make one party particularly vulnerable to coercive misconduct. See Michael Z. Green, Tackling Employment Discrimination with ADR: Does Mediation Offer a Shield for the Haves or Real Opportunity for the HaveNots?, 26 BERKELEY J. EMP. \& LAB. L. 321, 347-53 (2005); Phyllis Gangel-Jacob, Some Words of Caution About Divorce Mediation, 23 HofSTRA L. REV. 825, 833-35 (1995); Mori Irvine, Mediation: Is It Appropriate for Sexual Harassment Grievances?, 9 OHIO ST. J. ON DisP. RESOL. 27, 36-40 (1993). 
party cannot be forced to continue negotiating once he or she is unwilling to go forward. As I have heard many mediators say over the years, and have said before in my opening remarks when mediating a case, "I can't make you stay and I can't make you settle." 201 Notwithstanding, most mediation participants perceive that staying is in their best interest.

The second policy basis is more substantive. The mediation bargaining process, to be effective, requires a measure of candor from the parties, and to induce such candor a confidentiality rule must prevent the parties from disclosing substantive concessions regarding the merits of the case if the mediation fails to bring about a settlement. ${ }^{202}$ Concomitantly, preventing disclosure of substantive discussions in caucus preserves the neutrality of the mediator, insofar as he or she cannot be compelled to testify later regarding a party's admissions. ${ }^{203}$ Absent such protections, mediation would have much less chance of success, to the extent "success" is measured in terms of settlement. ${ }^{204}$

The protections afforded the mediator are compromised by the widespread local rules that impose a duty on the mediator to report perceived "bad faith" to the trial judge, ${ }^{205}$ given that her actions may result in the imposition of sanctions for one party and against another. Once again, Doe v.

201 Note, however, that some local rules reserve to the mediator the right to declare an impasse, suggesting that a mediator would, in fact, have the right to compel continued attendance, at least to a point. See, e.g., W.D.N.Y. PROPOSED R. 16.2-1(o)(3); M.D. PA. R. 16.8.6(b); N.D. GA. R 16.7(J)(3)(b); N.D. AlA. R. 16.1, ADR Plan R. IV(B)(9)(f).

202 See, e.g., Lake Utopia Paper Ltd., v. Connelly Containers, Inc., 608 F.2d 928, 930 (2d. Cir. 1979) ("If participants cannot rely on the confidential treatment of everything that transpires during these sessions then counsel of necessity will feel constrained to conduct themselves in a cautious, tight-lipped, non-committal manner more suitable to poker players in a high-stakes game than to adversaries attempting to arrive at a just resolution of a civil dispute. This atmosphere if allowed to exist would surely destroy the effectiveness of a [mediation] program."), quoted in Litt, supra note 31 , at 1020 .

203 Izumi \& La Rue, supra note 43 , at 82-84.

204 In fact, there is reason to question whether mediation has a substantive effect on the rate of settlement. As documented by Wissler, supra note 17, at 668 , the rate of settlement for mediated and non-mediated cases in her study were roughly the same. The fact is that most cases settle whether they are mediated or not, although the quality of the settlement may arguably be better, in the sense that participants perceive that it is more "fair", if it is the result of a mediation. Id. at 661-67.

205 See, e.g., E.D. Mo. R. 16-6.05(A); D. NEB. GEN. R. 1.2(h), Mediation Plan R. 4(g); see also JEFFREY M. SENGER, FEDERAL DISPUTE RESOLUTION: USING ADR WITH THE UNITED STATES GOVERNMENT 178-79 (2003) (discussing importance of confidentiality to maintain mediator impartiality). 
Francis provides the most extreme example of where this can lead. The mediator in that case was ordered to provide periodic updates to the judge, during the mediation session, regarding whether he thought the parties were making progress toward settlement. ${ }^{206} \mathrm{~A}$ negative evaluation by the mediator could have resulted in the judge reinstating the contempt order and sending Francis to jail. It is difficult to imagine how a mediator, even a very good one as in this case ${ }^{207}$ could maintain a patina of neutrality when his contact with the judge indirectly gave him the keys to the jailhouse door.

The mediator's role in a good faith compliance scheme constitutes a fundamental alteration of the mediation process, substantially reducing the mediator's efficacy by transforming him into a witness and an arbiter of the parties' compliance with a mediation referral order. ${ }^{208} \mathrm{~A}$ mediator's ability to facilitate resolution of a dispute turns upon his ability to convey a genuine impartiality toward the parties, ${ }^{209}$ particularly given his role in "realitytesting" the positions parties bring with them into the negotiations. ${ }^{210}$ The knowledge that the mediator may ultimately be called upon to testify regarding what transpired in caucus will logically cause parties to hold back information 211 and take steps designed not to move the case toward settlement, but to prove to the mediator that they prepared for the mediation

206 Francis, 18 Fla. L. Weekly Fed. D at 241 (order).

207 The mediator in the Francis case was Dominic Caparello, a partner in the law firm of Messer, Caparello \& Self in Tallahassee, Florida. Caparello is one of the most established and well-respected mediators in Florida. See profile at http://www.lawfla.com/Lawyers/Dominic-M-Caparello.aspx (last visited Feb. 24, 2010).

208 See Nancy A. Welsh, The Place of Court-Connected Mediation in a Democratic Justice System, 5 CARDOZo J. CONFLICT RESOL. 117, 136-37 (2004) ("[A]s the courts have come to rely on mediators as the next set of judging adjuncts, the mediation process and the roles of both mediators and parties have changed.").

209 See N.L.R.B. v. Joseph Macaluso, Inc., 618 F.2d 51, 55-56 (9th Cir. 1980) ("To execute successfully their function of assisting in the settlement of labor disputes, the conciliators must maintain a reputation for impartiality.... If conciliators were permitted or required to testify about their activities, or if the production of notes or reports of their activities could be required, not even the strictest adherence to purely factual matters would prevent the evidence from favoring or seeming to favor one side or the other. The inevitable result would be that the usefulness of the [conciliators] in the settlement of future disputes would be seriously impaired, if not destroyed."), quoted in SENGER, supra note 205 , at 179 .

210 See Deason, supra note 17 , at 564 ("Mediator neutrality, 'a primary value of mediation,' depends on the mediator's ability to avoid taking sides. Neutrality is impossible, however, if a mediator is called to testify about events in a mediation....") (internal quotation and citation omitted).

211 Litt, supra note 31, at 1022. 


\section{IS IT TIME FOR A FEDERAL MEDIATION EXCLUSIONARY RULE?}

and appeared in good faith. Further, one must question exactly what sort of questions a mediator may fairly ask in caucus, knowing that the responses may become a matter of public record. Can a mediator remain neutral, while at the same time potentially serving as the court's witness regarding whether a party had prepared or negotiated in good faith? ${ }^{212}$

Moreover, although the various district court rules contain sometimes elaborate procedures to address the issue of good faith, they give little attention to the growing problem of using a mediation sanctions motion as a coercive tool in negotiations. ${ }^{213}$ A review of the district courts' rules regarding confidentiality, good faith, and the reporting obligations of mediators demonstrates that while these rules sometimes appear to recognize directly or indirectly the policy consideration of candor, to some degree, they do not address the issue of coercive use of sanctions motions at all. In fact, as discussed elsewhere in this article, ${ }^{214}$ several courts have provided a vehicle for such coercive conduct by setting up separate tribunals tasked with consideration of sanctions for alleged misconduct in court-ordered ADR proceedings. ${ }^{215}$ Thus, if anything the courts have facilitated this sort of litigation.

In practice, mediation confidentiality in the federal courts amounts to little more than the protections already embodied in Federal Rule of Evidence 408, preventing the introduction of a compromise statement for the

212 For example, N.D. GA. R. 16.7(H)(d), provides a list of questions the parties must be prepared to answer for the mediator. Is the mediator to appraise the parties' good faith based on their answers to these questions?

213 The problem of using as a coercive tool a rule designed to deter abuse of the judicial process is not a new one. With the advent of FED. R. CIV. P. 11 in 1983, the courts saw a flood of sanctions motions that were filed almost de rigueur in response to any filing or action by the opposing party that could form a marginally supportable basis for sanctions. See Georgene M. Vairo, Rule 11: A Critical Analysis, 118 F.R.D. 189, 197-200 (1988). In response to this misuse of Rule 11, it was amended a decade later to curb this abuse of a rule designed to curb abuse. The reform conferred discretion upon the courts with regard to the imposition of sanctions (they had previously been mandatory if the court found a Rule 11 violation), and provided a twenty-one day safe harbor within which a party could withdraw an otherwise sanctionable filing. FED. R. CIV. P. 11 advisory committee's notes to 1993 amendment; see also Matthew G. Vansuch, Icing the Judicial Hellholes: Congress' Attempt to Put Out "Frivolous" Lawsuits Burns a Hole Through the Constitution, 30 SETON HALL LEGIS. J. 249, 295-98 (2006).

214 See infra text accompanying notes 226-27.

215 See, e.g., S.D. GA. R. 16.7.7(b) (report to clerk); D. UTAH CIv. R. 16-2(j)(1), ADR Plan $\S 6(\mathrm{i})(2)(\mathrm{C})$ (same); N.D. OHIO CIV. R. 16.6(g)(5) (report to ADR Administrator); W.D. Mich. R. 16.4(d) (same); E.D. CAL. CIV. R. 271(n)(1) (same) and 271(o)(1) (report to judge). 
purpose of proving liability or damages. ${ }^{216}$ In fact, some courts have expressly crafted their rules of mediation confidentiality to be coextensive with Rule $408 .{ }^{217}$ Such a narrow application of the policy considerations inherent in mediation, as opposed to other ADR processes, transforms mediation into little more than a judicial settlement conference with the mediator standing as a proxy for the judge or special master.

Finally, the development of an elaborate good faith sanctions scheme to ensure compliance with mediation referral orders harms the mediation process by moving further in the direction of litigizing it. Over the last three decades, mediation has absorbed far more of the courthouse than the courthouse of mediation, and commentators have observed that mediation has been degraded by absorbing litigation values such as adversarialness. ${ }^{218}$ With the adoption of mediation as a docket management tool has come a multi-layered system of oversight into the qualifications of mediators, the scheduling and basic structure of mediation, the general ground rules for participation, and now extremely detailed direction from many district courts regarding how the court demands that the parties participate. ${ }^{219}$ In a way, the district judge's order directing Joe Francis to appear at mediation with closed-toed shoes was just another step in this process. 220

Recognizing a limited rule of mediation confidentiality offers the opportunity to arrest this trend by drawing a line at the mediation conference door beyond which the court may not intrude or inquire. It allows mediation to remain mediation, with all of the messiness and flexibility inherent in a process driven by the participants rather than the judge. It also, as discussed below, advances the very goal that led courts to embrace mediation instead of the judicial settlement conference, insofar as protecting confidentiality will almost certainly lead to less judicial workload, and more settlements.

\section{B. Outcome-Based Arguments for a Rule of Exclusion}

One might argue that the federal courts should have the ability to craft their own version of what constitutes mediation because of its utility as a docket management tool. Perhaps if parties are given free reign to say or do

216 FED. R. EVID. 408; SENGER, supra note 205, at 188.

217 See, e.g., S.D. ALA. R. 16.6, ADR Plan R. IV(A)(11); cf. Doe v. Nebraska, 971 F. Supp. 1305, 1307 (D. Neb. 1997) (framing reasons for mediation confidentiality rule in terms of Rule 408 policy goals).

218 Izumi \& La Rue, supra note 43, at 92-97.

219 See N.D.N.Y R. 83.11-5, for example.

220 See supra text accompanying notes 71-72. 


\section{IS IT TIME FOR A FEDERAL MEDIATION EXCLUSIONARY RULE?}

what they want at mediation, fewer cases will settle and the purposes of the ADR Act, as well as the inherent authority of the trial courts to manage their dockets, will be undermined. This argument has particular appeal when taken from the abstract to the specific: Who could argue that a litigant's right to harangue his opponents with obscenities, or to make a ridiculously low offer that reflects no meaningful evaluation of the case, should be protected ${ }^{221}$ Is there a right to boorish behavior, particularly when it means a more crowded federal docket?

The responses to this line of reasoning are threefold. First, there is no evidence that the district courts' ability to monitor litigants' behavior at court-ordered mediation has appreciably reduced the size of the trial docket. In fact, if one shifts focus from the number of cases that have settled at mediation to the volume of motions related to mediation misconduct that have been filed over the decade since the passage of the ADR Act, it appears that the self-imposed obligation to monitor the integrity of the mediation process has actually increased the workload of the district courts. ${ }^{222}$ Two developments infer such a conclusion. First, a review of the reported and unreported district court rulings ${ }^{223}$ related to alleged mediation misconduct shows an upward trend over the last several years, ${ }^{224}$ when previously such motions, though not unknown, were significantly more rare. ${ }^{25}$ Thus, empirically the imposition of a mediation mandate has apparently created new grist for motion practice. This observation is borne out by the designation in some district courts of a "Compliance Judge,"226 tasked with wading through sanctions motions in search of some deviation from the

221 Weston, supra note 35, at 604; see also Brazil, supra note 194, at 256 (arguing that providing mechanisms for parties to complain and seek relief from courts for failing to meet requirements of court-ordered ADR is positive, because this gives courts ability to develop standards, and "become sources of legal discipline and ethical guidance for the field at large.").

222 See supra Part II(A), for discussion of evolution of trial court monitoring of participation in court-ordered mediation.

223 This refers to the unreported decisions found on Westlaw and Lexis, not to every $\mathrm{CM} / \mathrm{ECF}$ filing over the last decade. That said, there is no reason to believe that the trend on $\mathrm{CM} / \mathrm{ECF}$ is materially different.

224 See Coben \& Thompson, supra note 60, at 52-53.

225 There were several decisions that followed the passage of the 1990 Act. See, e.g., Francis v. Women's Obstetrics and Gynecology Group, P.C., 144 F.R.D. 646, 646 (W.D.N.Y. 1992). Such motions and rulings appear to have been virtually unknown before then.

226 See, e.g., D. UTAH CIV. R. 16-2(i). 
express or implied obligation to mediate in good faith. ${ }^{227}$ Although such tribunals seem meant to advance the salutary goal of insulating the trial judge from being influenced by the recounting of one side's mediation pecadillos, the mere fact that such a forum exists suggests that court-annexed ADR programs have ironically increased judicial workload just as the volume of cases going to trial has declined.

Second, there is no reason to believe that a court's monitoring of the mediation process, or the corresponding threat of sanctions, has increased the efficacy of mediation as a settlement catalyst. In fact, if anything the erosion of confidentiality that necessarily accompanies increased judicial oversight almost certainly diminishes the likelihood that mediation will result in settlement. ${ }^{228}$ As discussed above, ${ }^{229}$ mediators rely on the candor of the parties to facilitate crafting solutions that advance or preserve the interests of both sides. A party that knows the substance of its negotiations may become the subject of a motion before the court will almost certainly become more measured in its disclosures, giving the mediator that much less with which to work. Likewise, an emotional outburst may well reflect the genuine feelings of a party toward an opponent or the litigation process in general. While such cathartic behavior may be uncomfortable for those in the room, it may well contribute to the understanding of the mediator or the opposing party of the actor's interests in the dispute, which in turn may provide insights into alternatives for resolution of the lawsuit. ${ }^{230}$ The threat of sanctions must necessarily dampen any such communications to the detriment of the effectiveness of the mediation process.

${ }^{227}$ Another variation on this theme is the designation of an ADR Program Administrator, who may be tasked with evaluating complaints of mediation misconduct and deciding whether judicial intervention is appropriate. See, e.g, C.D. ILL. R. 16.4-E(3) (providing for post-mediation reporting to court ADR Administrator).

228 One could at least infer that it was the lack of judicial oversight, and attendant increase in effectiveness as a vehicle for settling cases, that led to mediation's preference over the judicial settlement conference as a docket management tool. See Sherman, supra note 194, at 2082 (arguing that confidentiality is "essential to the capacity of an ADR proceeding to achieve a settlement.").

229 See supra text accompanying notes 202-12.

230 See Sherman, supra note 194, at 2093 ("ADR offers a process of assisted negotiation where the parties should be able to choose to be forthcoming and make concession or not. To deny them the right to take strong, or even extreme, positions (for example, that there is no liability or that a certain sum is the only basis on which a settlement is possible) would deprive them of litigant autonomy and the legitimate right to hold out and have those issues determined in a trial."); FISHER, URY, \& PATTON, supra note 196. 
Finally, there is no reason for treating mediation the same as any other process that could be lumped under the rubric of "ADR." A court has a spectrum of alternative dispute resolution vehicles available for the resolution of a given dispute, including arbitration, the settlement conference, early neutral evaluation, mini-trial or summary jury trial, among others. ${ }^{231}$ All of these carry with them different expectations with regard to confidentiality. Some district courts have been adept at crafting ADR rules that recognize these distinctions, and provide different standards depending on which type of ADR the parties employ, but this is the exception. ${ }^{232}$ Regardless, there is no reason that a district court must subject mediation to a Procrustean bed ${ }^{233}$ that eliminates or circumscribes confidentiality in the name of docket management, when other processes are available that do not rely heavily, or at all, on confidentiality as a principle.

In sum, judicial oversight of the quality of party participation in courtordered mediation does nothing to advance the goal of docket management, and in fact may inhibit this result. Parties' conduct and communication at mediation becomes circumscribed, creating fewer opportunities for the mediator to identify and address the interests giving rise to the dispute, and therefore fewer opportunities for settlement. At the same time, any party with the temerity to act out at a court-ordered mediation, or otherwise engage in what the other side views as a lack of good faith, will likely face a motion for sanctions that would never have been filed if the court had not invited it by crafting a rule that purports to monitor the parties' behavior. If the desired

231 For a good overview of the various ADR processes, see the "ADR Blue Book" of the U.S. District Court for the Northern District of California. "ADR Blue Book," Dispute Resolution Procedures in the Northem District Court of California, available at http://www.adr.cand.uscourts.gov/ (follow "Dispute Resolution Procedures in the Northern District of California - "ADR Blue Book"' hyperlink; then follow "Blue Book 3-09.pdf' hyperlink).

232 For instance, the Northern District of California has developed an extensive menu of processes within its court-annexed ADR program, including both evaluative and facilitative variations. See Wayne D. Brazil, Court ADR 25 Years After Pound: Have We Found a Better Way?, 18 OHIO ST. J. ON DiSP. ReSOL. 93, 109-12 (2002) (describing evolution of Northem District's ADR program).

233 A Procrustean bed is "a scheme or pattern into which someone or something is arbitrarily forced." MERRIAM-WEBSTER's COLLEGIATE DiCTIONARY 990 (11th ed. 2003). The term refers to Procrustes, who maintained an iron bed on which passersby were invited to lie. If they were too tall, he would amputate the excess length of their legs; if too short, he would stretch them on a rack. HUTCHISON DICTIONARY OF WORLD MYTHOLOGY 197-98 (2005). 
result of engrafting mediation into a court-annexed ADR program is more settlements, the current regime appears ill-suited to advance that goal.

\section{IMPLEMENTING A MEDIATION EXCLUSIONARY RULE: ANSWERING THE "HOW" QUESTION}

As described above, the federal district courts have reacted unevenly to Congress's mandate to implement mandatory ADR programs that include rules protecting confidentiality. ${ }^{234}$ Some have adopted such rules, and some have not. Most have substantially disregarded any recognition of mediation confidentiality, regardless of the existence of a confidentiality provision in their local rules, when inquiring as to whether the parties participated in mediation in good faith. ${ }^{235}$ What has evolved as a result is not really mediation at all, at least not as the term is generally understood by lawyers and mediators. Rather, what is called "mediation" in a typical uniform scheduling order could more properly be understood as a variation on the judicial settlement conference, with the mediator acting as a sort of special master with the duty to report to the court as to what transpired. ${ }^{236}$

At the same time, the district courts have the authority, and perhaps in some situations the duty, to ensure compliance with their orders. An order referring a case to mediation would be meaningless if the parties simply could decline to attend. The question, however, is the extent to which the courts can and should monitor compliance with their mediation referral orders once the mediation begins, particularly in light of the fact that most federal courts at least purport to recognize some level of confidentiality with regard to what transpires there. This article does not advance the proposition that a district court has no role in monitoring its ADR program, but instead suggests that if the parties opt for the ADR device called "mediation," among a spectrum of options, they should be treated as having opted out of the level of judicial supervision that has become increasingly common in federal court.

234 See supra Part I.B.1.

235 See id.

236 See Ettie Ward, Mandatory Court-Annexed Alternative Dispute Resolution in the United States Federal Courts: Panacea or Pandemic?, 81 ST. JoHN's L. REV. 77, 95 (2007) ("[T]here is increasing acknowledgement that at least some court-annexed ADR is morphing into yet another version of the traditional settlement conference."); Welsh, supra note 12. 


\section{IS IT TIME FOR A FEDERAL MEDIATION EXCLUSIONARY RULE?}

As discussed previously, mediation is different. ${ }^{237}$ Unlike other ADR processes, mediation's bedrocks are party autonomy, undergirded by the premise that nothing one says at mediation will be used against that party if the case does not settle, and voluntariness - no one can be compelled to settle. The threat that a party will disclose what transpired at mediation in search of sanctions against the supposed miscreant party, particularly in light of the increasingly receptive attitude of the judiciary, has led inexorably toward the point where a party may face the decision, so succinctly stated in the press with regard to the GGW case, of "settle or jail."238

This is not to say that the federal courts should adopt a blanket mediation privilege. Most commentators, ${ }^{239}$ as well as the drafters of state privilege statutes and the Uniform Mediation Act, have recognized the need for exceptions to mediation confidentiality for matters such as attorney ethics violations and threats of violent or criminal behavior. ${ }^{240}$ The fact that these sources are largely consistent in their conclusions with regard to exceptions to mediation confidentiality, and that no state or uniform exception has been recognized for lapses of "good faith," speaks volumes about the wisdom of expanding the list to include such an exception. 241

It is time for the federal courts to provide some level of uniform mediation confidentiality, as mandated by the very language of the ADR Act

237 See Thompson, supra note 14 , at 516 ("[M]ediation was designed as a very different alternative to adversarial dispute resolution.").

238 David Angier, Judge to Francis: Settle or Jail: 'Girl's Gone Wild' Producer Found in Contempt of Court, Panama CiTY News Herald, Mar. 31, 2007. The judge later disavowed this interpretation of his actions in a lengthy order in a later case, Pitts $v$. Francis, No. 5:07cv169-RS-EMT, 2008 U.S. Dist. LEXIS 93047 (N.D. Fla. Dec. 19, 2007) (court order on a motion for disqualification).

239 See, e.g., Mori Irvine, Serving Two Masters: The Obligation Under the Rules of Professional Conduct to Report Attorney Misconduct in a Confidential Mediation, 26 RuTGERS L.J. 155, 166 (1994); Jaime Alison Lee \& Carl Giesler, Case Comment, Confidentiality in Mediation, 3 HARV. NEGOT. L. REV. 285, 285-86 (1998) ("Valid exceptions to the confidentiality rule may exist; rulemakers, whether judicial or legislative, must weigh their policy implications and provide participants in advance with clear rules as to how they will be handled.").

240 UNIF. MEDIATION ACT $§ 6(a)$ (2001).

241 See, e.g., Izumi \& La Rue, supra note 43, at 67-68 (analyzing UMA's failure to recognize "good faith" exception to mediation privilege at $\S 7(\mathrm{a})$ of the UMA). At the same time, several states have, by rule or statute, imposed an obligation to participate in court-ordered mediation in good faith, even while failing to recognize an exception to their confidentiality rules to allow disclosure of alleged bad faith conduct. See, e.g., Miss. Mediation R. Civ. Litig. XV(A); N.J. CT. R. 1:40-4(g); N.M. Magis. CT. R. CIV. P. 2805(C); OKLA. STAT. tit. 12, § 1824(3) (2010). 
of 1998. Such a recognition need not approach ADR in plenary fashion, and therefore could leave open the possibility of more active judicial supervision of ADR through the selection of a process other than mediation. There are numerous options by which a court might protect mediation confidentiality, including privileges arising out of the common law or statute, or amendment of the rules of evidence or of civil procedure. As discussed below, the best means of stemming the erosion of confidentiality described in this article would entail the amendment of FRCP Rule 16 to exclude any evidence of mediation communications in support of a motion for sanctions under Rule 16.242

\section{A. Common Law Mediation Privilege}

One option for developing and implementing a mediation privilege is to recognize a federal common law mediation privilege. Pursuant to Federal Rule of Evidence 501, the federal courts may develop a common law privilege "in the light of reason and experience."243 Given the welldeveloped ADR programs now in place throughout the federal judiciary, coupled with a decade of experience in addressing the issues that have arisen from implementing and monitoring court-mandated mediation, the courts certainly have an ample experiential basis from which to develop a common law privilege that would shield mediation communications.

At the same time, this experience suggests that a common law privilege would be neither likely nor efficacious in addressing the issue of mediation confidentiality. The courts have now managed ADR programs for years, sometimes decades, and have yet to agree on a privilege. As of this writing, only two district courts have expressly recognized a mediation privilege, while the Sixth Circuit has adopted the far broader "settlement privilege" that seems to subsume mediation communications as a subset of a much broader rubric. ${ }^{244}$ Even in these jurisdictions, however, it is not clear that the privilege they have recognized necessarily serves to exclude evidence of communications in order to prove a violation of those jurisdictions' good faith obligations. Certainly the confidentiality protections incorporated into the district courts' local rules have done little to impede the consideration of these communications by courts faced with sanctions motions based on an

242 For a discussion of the distinction between use of an exclusionary rule and a privilege to protect mediation confidentiality, see Deason, supra note 17, at 574-75.

243 FED. R. EvID. 501.

244 See supra Part I(B)(2). 
alleged lack of good faith. Why would a common law rule be any more effective?

Besides the lack of uniformity of breadth among those courts that have recognized a mediation privilege, there is the problem of uneven application based on whether the issue before the court is considered to be one of federal or state law. As discussed above, Rule 501 mandates that state law privilege be applied whenever state law provides the rule of decision. ${ }^{245}$ This variable sets the stage for inconsistent application of a mediation privilege, based upon whether the trial judge frames the issue as one of state or federal law. Although perceived defiance of a court's good faith mandate may seem more a question of federal law, whether based on local rule or the inherent authority of the court, a judge or a creative sanctions movant could just as easily avoid the application of the privilege by characterizing the issue as a matter of state contract law, for instance by shoehorning the alleged "bad faith" into a common law basis for rescission of a mediation settlement agreement. 246

Finally, mediation does not present the sort of situation that calls for the creation of a privilege, rather than some more tailored form of protection. Privileges are generally meant to protect certain confidential relationships, such as attorney and client or physician and patient, that rely on confidentiality to protect and foster the relationship itself. ${ }^{247}$ In contrast, the parties to a mediation are two or more sets of adversaries, brought together in a process facilitated by a mediator who necessarily lacks a relationship with either side that extends beyond the mediation. Thus, the issue is not the extent to which the disclosure of confidential mediation communications might damage the parties' relationship; rather, it is the danger that disclosure will undermine the negotiating process by inhibiting candor and calling into question the impartiality of the mediator. ${ }^{248}$

245 FED. R. EVID. 501.

246 See Judge Brazil's analysis in Olam v. Cong. Mortg. Co., 68 F. Supp. 2d 1110, $1110,1119-28$ (N.D. Cal. 1999).

247 See Maureen E. Laflin, The Mediator as Fugu Chef: Preserving Protections Without Poisoning the Process, 49 S. TEX. L. REv. 943, 946 (2008) ("Privileges are meant to nurture specific interpersonal or professional relationships that courts, society, and legislatures deem desirable."); $c f$. Scott H. Hughes, The Uniform Mediation Act: To the Spoiled Go the Privileges, 85 MARQ. L. REV. 9, 24-34 (2001) (explaining difference between confidentiality and privilege, observing that privilege reflects "normative choice" to protect confidential relationship, while confidentiality entails both confidential relationship and affirmative duty to keep secrets).

${ }^{248}$ Laflin, supra note 247, at 946 ; see also supra discussion accompanying notes $202-12$. 
In sum, not only is the recognition of a federal common law mediation privilege unlikely after at least ten years without such protections, it would also fail to remedy the problem of providing predictability and decreasing the number of sanctions motions before the courts. Absent a mandate from the Supreme Court that does not appear forthcoming, one also faces the likelihood that a privilege or rule of confidentiality would vary in scope in the various jurisdictions where it is recognized. Given that this is a fair description of the present situation, it is hard to see such a development as an improvement.

\section{B. Statutory Mediation Privilege}

The most common means of protecting the confidentiality of mediation communications at the state level is through a statutory mediation privilege. Often this privilege mirrors the language of the UMA, or derives in part from the UMA. These statutory privileges benefit from a high level of detail regarding what is protected and what is not, providing specific lists of exceptions to the privilege which make its application predictable. ${ }^{249}$ Further, the state courts have developed a fairly robust body of case law interpreting their statutory mediation privileges, and how they dovetail with rule-based schemes for implementing court-managed ADR programs. Thus, a statutory privilege probably provides the most user-friendly means of understanding and complying with a confidentiality requirement.

Three considerations militate against the adoption of a statutory federal mediation privilege, however. First, as a practical matter, it may be difficult or impossible to aggregate the political capital required for such a proposal to make it through the legislative process. Second, and more substantive, is the concern that a comprehensive statutory mediation privilege, with detailed exceptions, may be more than is required to address the immediate problem. The district courts have answered the mandate of the ADR Act by creating local rules of confidentiality, and in most situations not involving sanctions for alleged mediation misconduct, these rules appear to have functioned effectively. If the issue providing impetus for a privilege is the surfeit of sanctions litigation arising out of supposed mediation bad faith, a far less comprehensive solution could achieve the end of upholding mediation values and keeping these sorts of disputes out of the courtroom. Finally, the

249 Regarding the desirability of predictability, and the difficulties of attaining it with regard to mediation confidentiality, see generally Ellen E. Deason, The Quest for Uniformity in Mediation Confidentiality: Foolish Consistency or Crucial Predictability?, 85 MARQ. L. REV. 79 (2001). 
adoption of a statutory mediation privilege is inconsistent with the mandate of the ADR Act. Congress's direction was that the district courts adopt local confidentiality rules "[u]ntil such time as rules are adopted under chapter 131 of this title providing for the confidentiality of alternative dispute resolution processes...."250 This was not an invitation for the judiciary to punt the issue back to Congress, but rather a directive that the courts eventually adopt a uniform rule that protects ADR confidentiality. The time for this step is now.

\section{Rule-Based Protection of Mediation Confidentiality}

The best option for protecting mediation confidentiality lies in amending FRCP Rule 16. As discussed above, this appears to have been the intent of Congress when it passed the ADR Act. ${ }^{251}$ Moreover, the abuses that have transpired regarding supposedly confidential mediation communications appearing in sanctions motions have evolved from an expansion of Rule 16's mandate of good faith participation at settlement conferences to include mediation. ${ }^{252}$ This blurring of the line between settlement conference and mediation pre-dated the body of local rules mandating good faith participation in court-ordered mediation, and in fact those later rules could be viewed as the implementation of this flawed premise. ${ }^{253}$

An amendment to Rule 16, saying simply that "mediation communications shall not be disclosed in a motion seeking sanctions under this rule," would be sufficiently narrow in its scope to leave the district courts with sufficient room to monitor compliance with their orders. Even with the increase in sanctions motions based on alleged bad faith at mediation, many of the motions still relate to failure to attend mediation at all, or attending by phone or with no independent authority to settle. ${ }^{254}$ Such motions would not be affected by a narrow rule of exclusion, and a court could still order parties to appear at a place and time for mediation. All it

\footnotetext{
25028 U.S.C. $\S 652$ (d) (2010).

251 See supra notes 27-30.

252 See supra Part II(A).

253 See id.
}

254 The author performed a search on Westlaw of the past five years of cases involving good faith and mediation sanctions. During that period, the search revealed thirty-five cases, of which most were decided in the last two years. This total does not include cases such as Doe v. Francis, which were never available on Westlaw. Of these, no less than ten related simply to the failure of a party to attend mediation, or the failure to attend with sufficient settlement authority. 
would lose is the ability to monitor and manipulate the quality of what transpires once the mediation conference begins. In addition, courts would still have the ability to consider evidence of what transpired at mediation for purposes unrelated to good faith, such as duress or fraud, as a basis for rescinding a mediation settlement agreement. Thus, a less sophisticated or weaker litigant would maintain the ability to seek judicial relief from the substantive effects of what might otherwise be framed as "bad faith," but not sanctions based on the same conduct. ${ }^{255}$

Notably, the proposed exclusionary rule would not apply in blanket form to ADR generally. It is difficult to see how some ADR processes, most notably arbitration or other such evaluative vehicles, are adversely impacted by the lack of a cloak of confidentiality as is mediation. ${ }^{256}$ Reviewing the case law that has developed since the CJRA and the ADR Act, there appears to have been little motion practice for lack of "good faith," or failure to abide by rules of confidentiality, associated with ADR processes other than mediation. ${ }^{257}$ This may be because non-mediation ADR is now more rare, or because confidentiality is neither expected nor necessary outside of the mediation context. Thus, although the ADR Act speaks in terms of providing a rule of confidentiality for ADR processes in general, the experience of the last several years suggests a more narrow approach.

Such a targeted exclusion would also provide a powerful tool for party autonomy. Those litigants who value a higher level of judicial supervision in ADR would have the ability to select a process that does not carry a mantle of confidentiality, leaving open the possibility of judicial intervention if the opposing party undermines the process in ways that the court considers bad faith or noncompliance with its ADR order. On the other hand, parties may prefer mediation, notwithstanding the lack of oversight and the risks that

255 Scholars have extensively discussed the possibility that mediation's confidentiality could be used as cover for aggressive behavior and negotiating tactics directed at less sophisticated or experienced parties. See, e.g., Weston, supra note 35, at 595, 604; $\mathrm{cf}$. Deason, supra note 143, at 248 (observing that some mediation statutes are incomplete in their coverage of need for disclosures in matters such as child abuse, ongoing crime and mediator misconduct); Welsh, supra note 208, at 135-40 (advocating increased judicial oversight to assure accountability of mediation process).

256 For a discussion of the importance of confidentiality in mediation, see supra Part IV. Note that although courts are less likely to impose a rule of confidentiality with regard to nonbinding arbitration, instead limiting the use of arbitration evidence in a subsequent trial de novo, courts employing early neutral evaluation generally treat these proceedings as confidential. See, e.g., N.D. CAL. ADR LoC. R. 5-1; N.D.N.Y. R. 83.128.

${ }^{257}$ Coben \& Thompson, supra note 60, at 119-22. 
accompany it, because it provides a better chance of settlement than a less opaque forum. Most experienced mediators and mediation participants have encountered catharsis, posturing and intransigence, the very stuff of "bad faith" in the eyes of some courts, as a presage to the eventual settlement of the dispute, with the recalcitrant party agreeing to pay or accept a monetary settlement at the end of the day. ${ }^{258}$ If mediation's advocates are to be believed, and the principles of party autonomy and mediator neutrality bear some functional relationship with the success of the mediation process as a means of resolving disputes, many litigants will likely conclude that the benefits of a confidential mediation are worth the risks. ${ }^{259}$

The implementation of such a narrow mediation rule of exclusion would substantially limit the opportunities for judicial oversight in cases such as those explored in Part II above. For instance, an attorney could take a hard line at mediation, refusing to budge from a prior settlement offer as did the attorney in Fisher, ${ }^{260}$ without fear of sanctions for what could be subjectively viewed as "bad faith." Likewise, a plaintiff may feel free to "ignore advice, cajoling, and common sense", as in Outar, ${ }^{261}$ if that is how he chooses to negotiate. The courts would retain the right to ensure good faith attendance, in the sense that the parties arrive at the appointed time and place, but their right to monitor participation would necessarily be circumscribed. ${ }^{262}$

So could a sanctions-seeking litigant bypass the proposed confidentiality rule simply by resting her motion not on FRCP Rule 16, but upon the "inherent authority" of the court? Based on the reasoning in Heileman, which to some degree is the wellspring from which subsequent decisions based on inherent authority to order good faith compliance with mediation orders flowed, the answer to this question is probably "no." The majority in Heileman viewed the district court's inherent authority as an adjunct to its rule-based authority. Thus, a court may rely on its inherent authority to effect

258 See Sherman, supra note 194, at 2093 ("Many of these same factors are fairly conventional tactics used by negotiators in law suits.").

259 See Kirtley, supra note 129 , at 8,15-19 (noting risks associated with informality of mediation, and weighing costs and benefits of heightened confidentiality).

${ }^{260}$ Fisher v. SmithKline Beecham Corp., No. 07-CV-0347A(F), 2008 WL 4501860 (W.D.N.Y. Sept. 29, 2008).

261 Outar v. Greno Indus., Inc., No. 03-CV-0916, at 2, 2005 WL 238740 (N.D.N.Y. Sept. 27, 2005).

262 Not all commentators see such a lack of judicial oversight as a good thing, however. See Thompson, supra note 14, at 565-72 (arguing that eclipse of facilitative mediation by more evaluative techniques, and courts' goal of settlement, requires increased judicial oversight in interest of public justice). 
the remedial purpose of Rule 16, specifically "to urge judges to make wider use of their powers and to manage actively their dockets from an early stage." 263 At the same time, a district court "may not exercise its inherent authority in a manner inconsistent with rule or statute,"264 and "“where the rules directly mandate a specific procedure to the exclusion of others, inherent authority is proscribed." 265 By this standard, a litigant could not skirt the express prohibition against disclosure of confidential mediation communications in a motion for sanctions under Rule 16 by simply saying it was instead seeking sanctions under the district court's inherent authority. Because the proposed amendment to Rule 16 bars the consideration or disclosure of confidential mediation communications, the space within which a court could rely on its inherent authority in this area would be circumscribed, and likely eliminated altogether.

Had a rule such as the one proposed in this article been in place in 2007, it probably would not have saved Joe Francis from sanctions, although he may have avoided a jail cell. Recall that Francis's obscene rant in the opening session was not his first affront of the day-he arrived at the mediation four hours late. If the trial judge's authority had been limited by a rule of confidentiality, he may never have heard what Francis said to the plaintiffs' attorneys, or how he acted in those explosive moments before they walked out of the room, but he could well have been apprised of the fact that Francis kept everyone waiting, at a cost of thousands of dollars an hour in attorneys' fees. ${ }^{266}$ Had the plaintiffs chosen to seek sanctions at that point, rather than spending another day negotiating with Francis after he had supposedly scuttled the entire mediation, they would have had a colorable argument that they were entitled to their fees for preparation and for spending half a day sitting in a hotel lobby waiting for the defendant, and could have sought their own and their clients' costs associated with attendance. The imposition of a mediation confidentiality rule would affect none of those remedies. 1989).

${ }^{263}$ G. Heileman Brewing Co., Inc. v. Joseph Oat Corp., 871 F.2d 648, 652 (7th Cir. 264 Id.

265 Id. (emphasis omitted) (quoting Landau \& Cleary, Ltd. v. Hribar Trucking, Inc., 867 F.2d 996, 1002 (7th Cir. 1989)).

266 There were four attorneys representing the plaintiffs at the mediation. Their fees, combined with those of the mediator, would have been well in excess of $\$ 1500-2000$ an hour. See Notice of Filing in Support of Motion for Sanctions, Doe v. Francis, 18 Fla. L. Weekly Fed. D 241, 241 (N.D. Fla. Oct. 8, 2003). 
So why was it a problem for the plaintiffs to go a step further, and recount what Francis said when he arrived? Simply put, there is no objectively measurable line between a communication meant to subvert the mediation process, and words offered to convey a party's unwillingness to bend on certain issues. The distinction between these purposes may lie in the mind of the speaker, but the words and motives are analyzed and delivered to the court through the prism of either a disappointed opposing party or an ostensibly neutral mediator. By allowing one's distaste for this defendant's choice of words, or perhaps his line of business, to color one's analysis of whether he deserved his fate, one loses sight of the fact that it is impossible to throw Francis into his jail cell without leaving the cell door open for every other litigant who may have the temerity to speak candidly in reliance on the supposed confidentiality of mediation.

\section{CONCLUSION}

Over the last two decades, the federal district courts have embraced mediation as their docket management tool of choice. In the process, they have changed the nature of mediation, and compromised its principles, in an attempt to integrate mediation into case management through the implementation of detailed rules prescribing not only the logistics of the process, but also the quality of parties' participation in mediation. Ironically, judicial efforts to monitor and advance the efficacy of mediation as a means of settling cases have undermined its effectiveness as a docket management tool, as the courts have faced an ever-growing number of sanctions motions for alleged bad faith noncompliance with mediation orders. By distorting the behavior of participants who are conscious of the possibility of monetary sanctions, or perhaps even jail, for failure to comply with the amorphous good faith standard, courts likely also undermine the effectiveness of mediation as a means of settling cases, thereby further adding to what some perceive as a crowded docket. Although indirect, the recognition of a narrow mediation exclusionary rule would arrest this trend, and preserve mediation as a distinct negotiation process. 


\section{APPENDIX}

| THE FIRST CIRCUIT

\begin{tabular}{|c|c|c|c|c|}
\hline & $\begin{array}{l}\text { District of } \\
\text { Maine }\end{array}$ & District of New Hampshire & \begin{tabular}{|l|} 
Distriat of \\
Mosssacharests
\end{tabular} & $\begin{array}{l}\text { District of } \\
\text { Fhode Islind }\end{array}$ \\
\hline $\begin{array}{l}\text { Exitence of } \\
\text { Mdminarory } \\
\text { Mlediation } \\
\text { Program }\end{array}$ & & & & \\
\hline $\begin{array}{c}\text { Bule of } \\
\text { Comfidentiality or } \\
\text { Privilege }\end{array}$ & 83.11(d) & 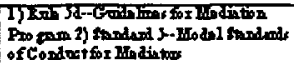 & $16.4(c) 4(f)$ & VII.AmIX. \\
\hline $\begin{array}{l}\text { Imposed } \\
\text { Obligation of } \\
\text { Good Faith }\end{array}$ & & 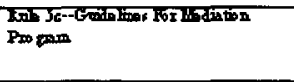 & & VII. (L) \\
\hline $\begin{array}{l}\text { Obligation wo } \\
\text { Report Btek To } \\
\text { Judge }\end{array}$ & & 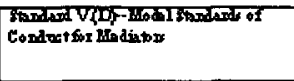 & $16.4(c) 4(d) \&(e)$ & 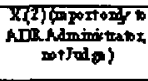 \\
\hline $\begin{array}{l}\text { Requirement of } \\
\text { Full Authanty to } \\
\text { Setrle }\end{array}$ & & 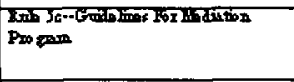 & & VII. (A) \\
\hline $\begin{array}{c}\text { Senctions for } \\
\text { Nencounglimes }\end{array}$ & & & & पII. (स) \\
\hline
\end{tabular}

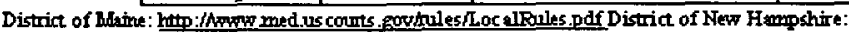

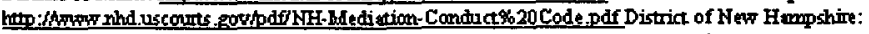

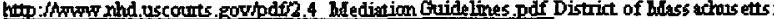

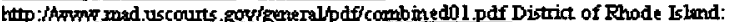

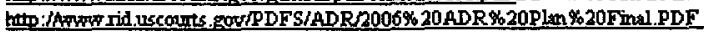


IS IT TIME FOR A FEDERAL MEDIATION EXCLUSIONARY RULE?

Third Circuit

\begin{tabular}{|c|c|c|c|c|c|c|}
\hline & $\begin{array}{l}\text { Eastem Dictrict of } \\
\text { Penrsytvania }\end{array}$ & $\begin{array}{l}\text { Wertem District } \\
\text { of Pernsylvania }\end{array}$ & $\begin{array}{l}\text { Midale } \\
\text { Distnict of } \\
\text { Pennoytvenia }\end{array}$ & $\begin{array}{l}\text { District of } \\
\text { Delaware }\end{array}$ & $\begin{array}{l}\text { District of } \\
\text { New Jersey }\end{array}$ & $\begin{array}{l}\text { District of the } \\
\text { Virgin } \\
\text { Ielends }\end{array}$ \\
\hline $\begin{array}{l}\text { Existence of Mandatory } \\
\text { Mediation Progrem }\end{array}$ & $53 x 496) ?$ & $32816.2 \mathrm{D}$ & $\begin{array}{l}\text { See bink to } \\
\text { stming ordex } \\
\text { belowor }\end{array}$ & $\begin{array}{l}\text { Does nof } \\
\text { unters } \\
\text { modition }\end{array}$ & $301.1(\mathrm{~d})$ & $32(0)$ \\
\hline $\begin{array}{l}\text { Rule of Confidentiality os } \\
\text { Privilege }\end{array}$ & $\begin{array}{l}53.3(3) \text { \& Frotosic. } \\
16(b)\end{array}$ & 61 & $16.8 .6 \mathrm{c})$ & & अणत(र)(4) & 5VIC. 584 \\
\hline $\begin{array}{l}\text { Imposed Obligation of } \\
\text { Good Fath }\end{array}$ & & & 168.72 & & Appentir Q 1 & $32(x)(2)$ \\
\hline $\begin{array}{l}\text { Obligation to Report Back } \\
\text { To Judge }\end{array}$ & Pन्याट. 1Б(19) & $\begin{array}{l}\text { 310 (xoport to } \\
\text { clets of court) }\end{array}$ & 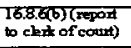 & & & 3य(स) (1) \\
\hline $\begin{array}{l}\text { Requirement of Full } \\
\text { Authority to Settle }\end{array}$ & Pाम & $38(4)(1) 2(2)$ & $168 \times(2)$ & & $301.1(6)(3)$ & $32(0)(2)(2)(b)$ \\
\hline Sonctions & PचांD.25 & $38(3)$ & 16.8 .72 & & A ppendix Q. III & $\begin{array}{l}32 \times(2) 8 \\
32(19)\end{array}$ \\
\hline
\end{tabular}

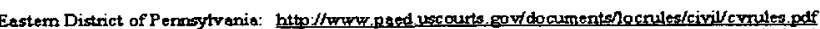

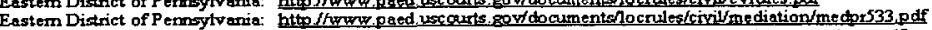

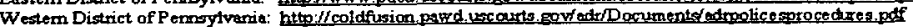

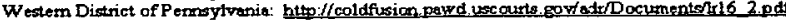

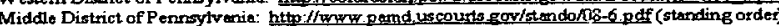

Middle District of Pennsylverie: hato:/twrww.pamd uscourts gov/d ocs/r120107.pdf

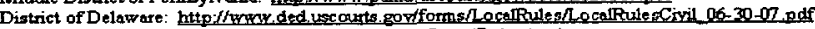

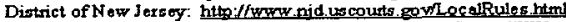

District of Yirgin Islends: htp://twrow vid. uscourts goy/Rules/CIVIL.gdf

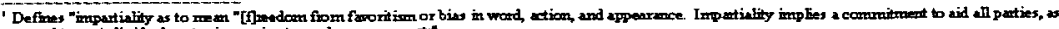

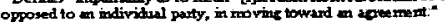

SECOND CIRCUIT

\begin{tabular}{|c|c|c|c|c|c|c|}
\hline & $\begin{array}{l}\text { Fastem District of } \\
\text { How Yodk }\end{array}$ & $\begin{array}{l}\text { Sonthem } \\
\text { District of } \\
\text { New Yodk }\end{array}$ & $\begin{array}{l}\text { Nanthem Distria of } \\
\text { New Your }\end{array}$ & $\begin{array}{l}\text { Werem Distial } \\
\text { of Kevr Yodk } \\
\text { (proposed locil } \\
\text { nule) }\end{array}$ & $\begin{array}{l}\text { Disuict of } \\
\text { Vermome' }\end{array}$ & $\begin{array}{l}\text { District of } \\
\text { Comediont }\end{array}$ \\
\hline $\begin{array}{l}\text { Bristence of } \\
\text { Manditacy } \\
\text { Mudiation Progrea }\end{array}$ & $83.11(b)$ & $83.12(e)$ & $83.11-3(0)$ & $16.2-1(0)$ & $16.3(6)$ & \\
\hline $\begin{array}{l}\text { Rile of } \\
\text { Cocfidentiality ar } \\
\text { Prisileg }\end{array}$ & $83.11(\mathrm{~d})$ & $83.12(k)$ & $83.11-5(\mathrm{~d})$ & $16.2-1(n)$ & $16.3(\mathrm{k})$ & his) \\
\hline $\begin{array}{l}\text { inposed Obligxtion } \\
\text { of Good Failh }\end{array}$ & & 83.120 & $83.11-5(c)$ & 16.2.1(1) & $16.3(1)(9)$ & \\
\hline $\begin{array}{l}\text { Obligution to Report } \\
\text { Buck To Judge }\end{array}$ & & $83.12(\mathrm{j})$ & $\begin{array}{l}83.11-6 \text { Ripocit to } \\
\text { ADR Cbenk, not } \\
\text { Jutge }\end{array}$ & $16.2-1(0)$ & $16.3(j)$ & $h(0)$ \\
\hline $\begin{array}{l}\text { Requirement of Full } \\
\text { Aurharity to Setthe }\end{array}$ & $83.11(\mathrm{c})(2)$ & $83.12(\mathrm{j})$ & $83.11 .5(b)$ & $16.2-1(6)$ & $16.3(8)$ & $h(3)(t)$ \\
\hline $\begin{array}{l}\text { Senctions for } \\
\text { Honvolomplenes }\end{array}$ & & & $83.11-5(d)(D)$ & $16.2-1(m)$ & $16.3(1)(5)$ & \\
\hline
\end{tabular}

Eastem District of New York: http:/Wurw.nued uscounts gov/adrMediationLocal Rule 8311 local_nule_8311_html Southem District of New York: htth:/whrw n nod.uscounts.gov/rulesinules.pdf

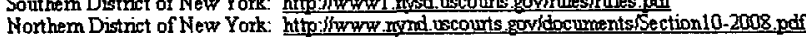

Westem District of New York: htp//www.mpand.uscounts.govkdocument/ProposedILR.1-1-08.pdf

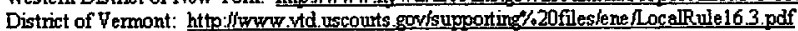

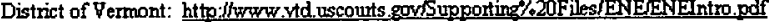

District of Connecticut: http:/hwww.ctd.uccounts goviPDF\%20Documents/local rules.pdf

1 The specific type of Altemutive Dispute Resobtion (ADR) progrm

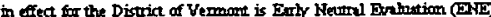
The roles mid procedires goveming Vermont's progam are deteiled oy Local Rult of Procedure 16.3. Sinsilar tomost ADR ar medirtion prograns in use by other feder al courts, the purpose of Vemmont's bNE progem is to reture cost, delyy and potential litigationficed by the

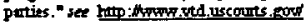


THE FOURTH CIRCUTT

\begin{tabular}{|c|c|c|c|c|c|c|c|c|c|}
\hline & $\begin{array}{l}\text { District of } \\
\text { South } \\
\text { Coroline }\end{array}$ & $\begin{array}{l}\text { Westem } \\
\text { District } \\
\text { North } \\
\text { Caroling }\end{array}$ & \begin{tabular}{|l} 
Middle \\
District \\
North \\
Carolina \\
\end{tabular} & $\begin{array}{l}\text { Eastem } \\
\text { District } \\
\text { North } \\
\text { Carolina }\end{array}$ & $\begin{array}{l}\text { Eastem } \\
\text { District } \\
\text { Virginia }\end{array}$ & $\begin{array}{l}\text { Westem } \\
\text { District } \\
\text { Virginia }\end{array}$ & $\begin{array}{l}\text { Southem } \\
\text { District } \\
\text { W. } \\
\text { Virginis }\end{array}$ & $\begin{array}{l}\text { Northem } \\
\text { District } \\
\text { W. } \\
\text { Virginia }\end{array}$ & $\begin{array}{l}\text { District of } \\
\text { Meryland }\end{array}$ \\
\hline $\begin{array}{l}\text { Existence of } \\
\text { Mandatory } \\
\text { Mediation } \\
\text { Program }\end{array}$ & $\begin{array}{l}16038 \\
1605\end{array}$ & $162(\mathrm{~A})$ & $\begin{array}{c}16.4 \& \\
8399(d)(d)\end{array}$ & $101(b)$ & & & & $1606(a)$ & \\
\hline $\begin{array}{c}\text { Rule of } \\
\text { Confidentiolity } \\
\text { of Privilege }\end{array}$ & $16 \cos (\mathrm{C})$ & $\begin{array}{l}\text { 16 YGXI) } \\
\text { N.C. Gen. Std. } \\
\text { s7a-38.1 }\end{array}$ & & $101.12(5)$ & $836(\bar{b})$ & $\begin{array}{l}\text { Stanthe } \\
\text { Oxdar: } \\
\text { L(A)(9)(E) }\end{array}$ & 1663 & 16Dद(e) & 60\%(4) \\
\hline $\begin{array}{l}\text { Imposed } \\
\text { Obligation of } \\
\text { Good Fath }\end{array}$ & & & & & & & & 16Dद(d) & \\
\hline $\begin{array}{l}\text { Obligation to } \\
\text { Report Back to } \\
\text { Jodpe }\end{array}$ & 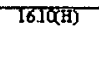 & $163(\mathrm{C} \times 3)$ & $839(6)$ & Tol.1e & $83 B(B)$ & & 1668 & 1606(0) & \\
\hline $\begin{array}{l}\text { Requinement of } \\
\text { Futl A uthority } \\
\text { to Settle }\end{array}$ & 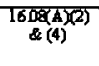 & $163(\mathrm{D} X 2)$ & $839 e(d)(1)(3)$ & 101.1 (d) & $836(\mathrm{H})$ & & T664 & 1605 & 6073 \\
\hline $\begin{array}{l}\text { Senctions for } \\
\text { Noncompliance }\end{array}$ & 1609 & $\begin{array}{c}\text { F.C. Gen. Stat. } \\
\text { S7A-38.1(d) } \\
\text { (2008 N.C. Lews } \\
\text { S.L. 2008 194 } \\
\text { (H.B. S4S) }\end{array}$ & $\begin{array}{l}83.4 a \\
839 e(h)\end{array}$ & $101.12(\mathrm{~h})$ & & & 163 & 350 & \\
\hline
\end{tabular}

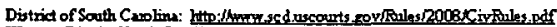

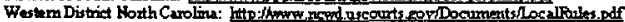

Midthe District Hath Caroline:

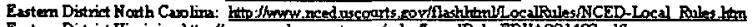

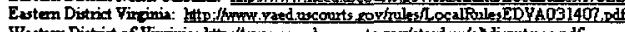

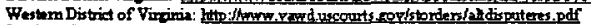

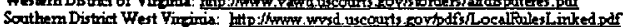

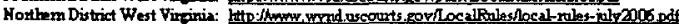

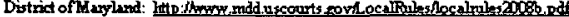

Sth Circuit

\begin{tabular}{|c|c|c|c|c|c|c|c|c|c|}
\hline & \begin{tabular}{|l} 
Southem \\
District of \\
Texes
\end{tabular} & $\begin{array}{l}\text { Worthem } \\
\text { District } \\
\text { of Texas }\end{array}$ & $\begin{array}{l}\text { Eastem } \\
\text { District } \\
\text { of Texas }\end{array}$ & $\begin{array}{l}\text { Westem } \\
\text { District of } \\
\text { Texas }\end{array}$ & $\begin{array}{l}\text { Westem } \\
\text { District } \\
\text { of } \\
\text { Louisiana }\end{array}$ & $\begin{array}{l}\text { Esstem } \\
\text { District } \\
\text { of } \\
\text { Lourisiena }\end{array}$ & $\begin{array}{l}\text { Middle } \\
\text { District } \\
\text { of } \\
\text { Louisiana }\end{array}$ & $\begin{array}{l}\text { Northern } \\
\text { District } \\
\text { of Miss. }\end{array}$ & $\begin{array}{l}\text { Southem } \\
\text { District } \\
\text { of Miss. }\end{array}$ \\
\hline $\begin{array}{l}\text { Existence of Mandatory } \\
\text { Mediation Program }\end{array}$ & $\begin{array}{l}16.4 . \mathrm{B}(2) \& \\
16 . \mathrm{C}^{2}\end{array}$ & & $\begin{array}{l}\text { Appentix } \\
\text { H. VI. }\end{array}$ & C8-88(c) & & & $c+2(a)$ & $83.7(5)$ & $83.7(8)$ \\
\hline $\begin{array}{l}\text { Rule of Confidentiality } \\
\text { or Privilege }\end{array}$ & 16.4 .1 & & $\begin{array}{l}\text { Appendix } \\
\text { H. VIII. }\end{array}$ & CV-88(2) & $1631 \%$ & 163.1हक & $E-3(0)$ & $83.7 \times(1)$ & 83.र(ख्रा) \\
\hline $\begin{array}{l}\text { Imposed Obligation of } \\
\text { Good } F \text { aith }\end{array}$ & & & & & & & & $83.7 \mathrm{~K}$ & $83 . \%(\mathrm{H})$ \\
\hline $\begin{array}{l}\text { Obligation to Report } \\
\text { Beck to Judge }\end{array}$ & $\begin{array}{l}6.4 \mathrm{R} \text { (xeport } \\
\text { to } \mathrm{ADR} \\
\text { Administator) }\end{array}$ & & $\begin{array}{l}\text { Appeadia } \\
\text { H. IX. }\end{array}$ & CF-88(h) & [63]W & & $\begin{array}{l}\text { E-6 (nepot } \\
\text { to } A D R \\
\text { chik) }\end{array}$ & $83.7(535)$ & $83.7(3)$ \\
\hline $\begin{array}{l}\text { Requirement of Full } \\
\text { Authosity to Setule }\end{array}$ & $16.4 . F$ & & $\begin{array}{l}\text { Appendix } \\
\text { H. VII. B. }\end{array}$ & CV 8 \& & & & $2-3(2)$ & $83 \% G(2)$ & $83.7(G)$ \\
\hline Senctions & $16.4 \mathrm{M}$ & & & CV-88(1) & & & $C-x_{a}$ & $83.7(\mathrm{H})$ & $837(\mathrm{H})$ \\
\hline
\end{tabular}

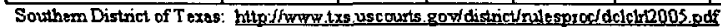

Northem District of Texes: http://wrw tenduscourts gow odfCIVRULES pdf

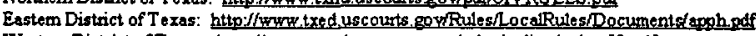

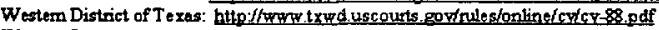

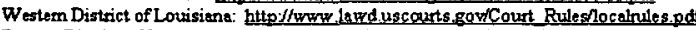

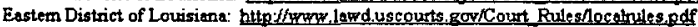

Middle District of Lotisiens: htto/hurnw laed uscourts. gor/LocalRules/adr\%20 baton\%20rouge. btom

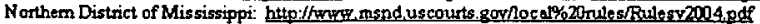

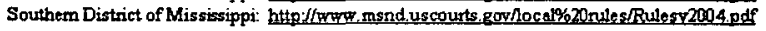


IS IT TIME FOR A FEDERAL MEDIATION EXCLUSIONARY RULE?

Sixth Circuit

\begin{tabular}{|c|c|c|c|c|c|c|c|c|c|}
\hline & \begin{tabular}{|l} 
Eastem \\
District of \\
Michigan
\end{tabular} & \begin{tabular}{|l} 
Westem \\
District of \\
Michizen
\end{tabular} & $\begin{array}{l}\text { Westem } \\
\text { District } \\
\text { of } \\
\text { Kentucky }\end{array}$ & \begin{tabular}{|l|} 
Eastem \\
District \\
of \\
Kentweky \\
\end{tabular} & $\begin{array}{l}\text { Worthem } \\
\text { District of } \\
\text { Ohin }\end{array}$ & $\begin{array}{l}\text { Southem } \\
\text { District } \\
\text { of Ohio }\end{array}$ & \begin{tabular}{|l|} 
Westem \\
District of \\
Tennessee
\end{tabular} & \begin{tabular}{|l|} 
Eastemn \\
District of \\
Tennessee
\end{tabular} & $\begin{array}{l}\text { Middle } \\
\text { District of } \\
\text { Tennessee }\end{array}$ \\
\hline $\begin{array}{l}\text { Daistence of } \\
\text { Monderay } \\
\text { Medition } \\
\text { Progern }\end{array}$ & $163(a)$ & & & & $16.6(2)$ & $163(2)(1)$ & $16.1(c)$ & 16.4(2) & $16.02(d \times 1)$ \\
\hline $\begin{array}{l}\text { Ralk of } \\
\text { Confidentialiny or } \\
\text { Privilese }\end{array}$ & & 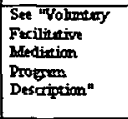 & 16.2 & 16.2 & $16.6(2)$ & 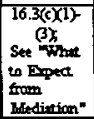 & & $16.4(h)$ & $16.08(0)$ \\
\hline $\begin{array}{l}\text { Oopliged } \\
\text { Good Fion of } \\
\text { Gith }\end{array}$ & & & & & & $16.3(9)(4)$ & & & \\
\hline $\begin{array}{l}\text { Dobliztion to } \\
\text { Repoent Back to } \\
\text { Sodze }\end{array}$ & & $\begin{array}{c}16.3(\mathrm{f}) \mathrm{ADR} \\
\text { Administrator }\end{array}$ & & & $\begin{array}{c}16.6(\mathrm{EXYS} \\
\mathrm{ADR} \\
\text { Administrator }\end{array}$ & $\begin{array}{l}\text { Ste What } \\
\text { to Expect } \\
\text { From } \\
\text { Mudinion }\end{array}$ & 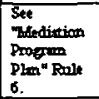 & $16.4(\mathrm{~m})$ & $16.05(0)$ \\
\hline $\begin{array}{l}\text { Requirumert of } \\
\text { Poll Asthority to } \\
\text { Sertle }\end{array}$ & & 16.3 (e)(ii) & & & $16.6(f)$ & $\begin{array}{l}\text { Set "What } \\
\text { to IDpect } \\
\text { From } \\
\text { Medietion" }\end{array}$ & $16.1(4)$ & 16.4(1) & $16.02(\mathrm{~d})(2)$ \\
\hline $\begin{array}{l}\text { Senctions ine } \\
\text { Nenceom limase }\end{array}$ & & & & & & $16.3(4)(4)$ & & $16.4(1)$ & $16.024)$ \\
\hline
\end{tabular}

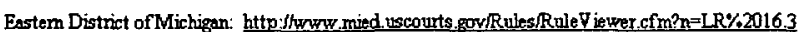

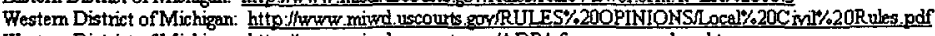
Westem District of Michigan: hittp/lwown mixnd.uscounts gor/ADR/vfm plogram desc.htm

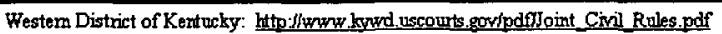

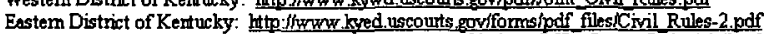

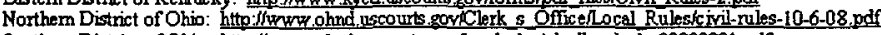

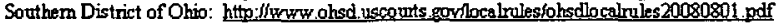

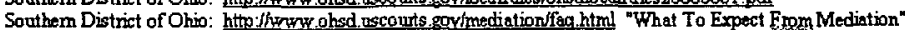

Westem District of Tennessee: http:/hwow, thurd uccouts. govfodficontent/LocalRules, pdf

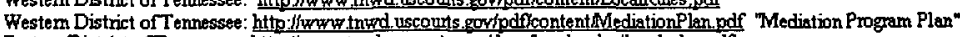

Eastem District of Temnessee: hith:/hwow thed uscourts govidocsfocal nules/lacahules odf

7th Circuit

\begin{tabular}{|c|c|c|c|c|c|c|c|}
\hline & $\begin{array}{l}\text { Northern } \\
\text { District of } \\
\text { Illinois } 1 \\
\end{array}$ & $\begin{array}{l}\text { Southern } \\
\text { District of } \\
\text { Illinois }\end{array}$ & $\begin{array}{l}\text { Central } \\
\text { District of } \\
\text { Illinois }\end{array}$ & $\begin{array}{l}\text { Northern } \\
\text { District of } \\
\text { Indiana }\end{array}$ & $\begin{array}{l}\text { Southern } \\
\text { District of } \\
\text { Indiana }\end{array}$ & $\begin{array}{l}\text { Eastern } \\
\text { District of } \\
\text { Wiscons in }\end{array}$ & $\begin{array}{l}\text { Westem } \\
\text { District of } \\
\text { Wisconsin }\end{array}$ \\
\hline $\begin{array}{l}\text { Exstence of } \\
\text { Mandatory Mediation } \\
\text { Proggem }\end{array}$ & & $163(a)$ & & $16,6(a)$ & & $16.5(\mathrm{a})$ & \\
\hline $\begin{array}{l}\text { Rule of Confidentiality } \\
\text { of Privilege }\end{array}$ & $16.3(c) ; 83.5$ & & $16.4 \mathrm{EX}(\mathrm{T})$ & $\begin{array}{l}\text { 16.6(c);see } \\
\text { Westhw and } \\
\text { lintiane statute } \\
\text { entitled: } \\
\text { - Altenative } \\
\text { Disputt } \\
\text { Resolution } \\
\text { Rule 2.11" }\end{array}$ & $\begin{array}{l}\text { See Westlaw and } \\
\text { Indiana statute } \\
\text { entitled: } \\
\text { "S.D.Ind A.D.R. } \\
\text { Rube 1.6" }\end{array}$ & 16.6 & $16.6(B)$ \\
\hline $\begin{array}{l}\text { Imposed Obligation of } \\
\text { Good Faith }\end{array}$ & & & & $\begin{array}{l}\text { I6.G(c); set } \\
\text { Westluw and } \\
\text { Indiana statute } \\
\text { entitled: } \\
\text { "Altemative } \\
\text { Dispute } \\
\text { Resolution } \\
\text { Rule 2.1" }\end{array}$ & $\begin{array}{l}\text { See Whestinw and } \\
\text { Indiand statute } \\
\text { entitled: } \\
\text { S.D.Ind A D.R } \\
\text { Rule 2.1" }\end{array}$ & & \\
\hline $\begin{array}{l}\text { Obligation to Report } \\
\text { Beck to Judge }\end{array}$ & $\begin{array}{l}\text { Appentix B. } \\
\text { VII. (A) }\end{array}$ & & $\begin{array}{c}\text { I6.4(E)(3) } \\
\text { Report to ADR } \\
\text { Administrator }\end{array}$ & $\begin{array}{l}\text { I6G(c); see } \\
\text { Westinu and } \\
\text { Inctions statute } \\
\text { entitled: } \\
\text { "Alternative } \\
\text { Dispute } \\
\text { Resolution } \\
\text { Rale 2.?(E)" }\end{array}$ & $\begin{array}{l}\text { See Westho and } \\
\text { Indiana statute } \\
\text { entitled: } \\
\text { S.D.Ind. A D R } \\
2.6(\text { (e)K1) }\end{array}$ & & \\
\hline $\begin{array}{l}\text { Requitement of Folf } \\
\text { A utbonity to Settle }\end{array}$ & $\begin{array}{l}\text { Appendir B. } \\
\text { VI (G) }\end{array}$ & & $16.4(E)(6)$ & $\begin{array}{l}16.6(c) ; 800 \\
\text { Westhus and }\end{array}$ & $\begin{array}{l}\text { See Westant and } \\
\text { Imtiana stafute }\end{array}$ & & \\
\hline
\end{tabular}

"Applies only to the Federal Trademark Act of 1946 ("the Lanham Act") 


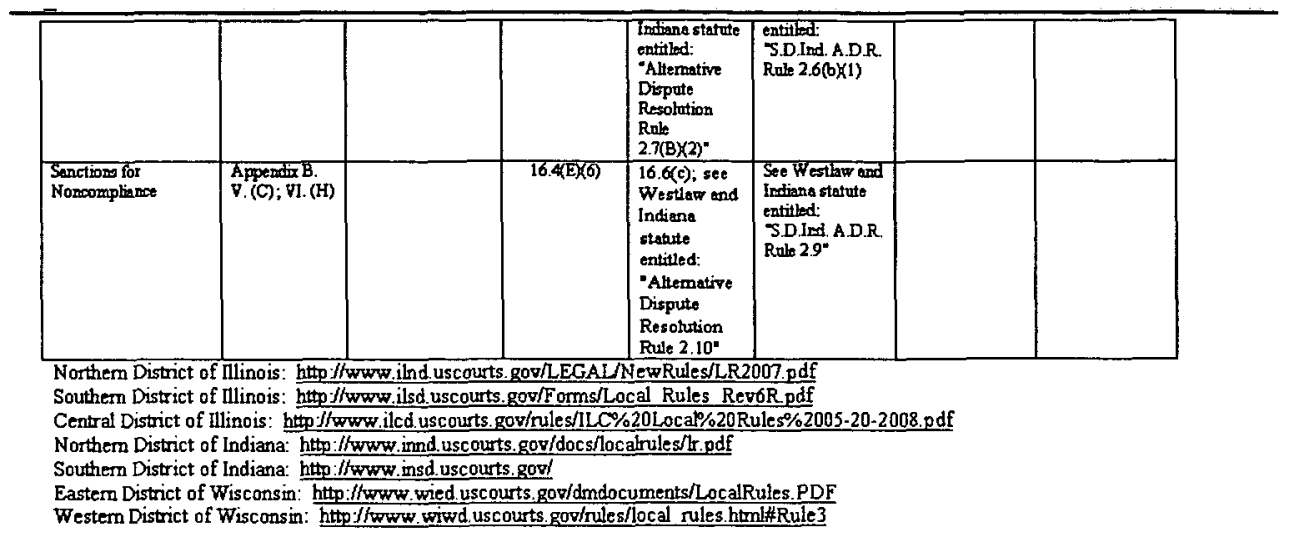

\begin{tabular}{|c|c|c|c|c|c|c|c|c|c|c|}
\hline \multicolumn{11}{|c|}{ Sth Cinnit } \\
\hline & $\begin{array}{l}\text { District of } \\
\text { Nanth } \\
\text { Dakote }\end{array}$ & $\begin{array}{l}\text { District of } \\
\text { Sormh } \\
\text { Dekota }\end{array}$ & \begin{tabular}{|l|} 
District of \\
Nebreske
\end{tabular} & $\begin{array}{l}\text { District of } \\
\text { Witmesoth }\end{array}$ & \begin{tabular}{|l|} 
Bastem \\
Disurica \\
of \\
Ankmses
\end{tabular} & $\begin{array}{l}\text { Wiestem } \\
\text { Distrit } \\
\text { of } \\
\text { Ankmses }\end{array}$ & $\begin{array}{l}\text { Bastem } \\
\text { Distrin of } \\
\text { Missouri }\end{array}$ & $\begin{array}{l}\text { Westem } \\
\text { Ditriat of } \\
\text { Missouri }\end{array}$ & $\begin{array}{l}\text { Sorthem } \\
\text { Discrict of } \\
\text { bown }\end{array}$ & \begin{tabular}{|l|} 
Northent \\
Ditartat \\
of bown
\end{tabular} \\
\hline $\begin{array}{l}\text { Bristence of } \\
\text { Mlenderay } \\
\text { Blediation } \\
\text { Progam }\end{array}$ & $16.2(\mathrm{~B})$ & & Ponle 2 & $16 . S(2)(2)^{1}$ & \begin{tabular}{|l|} 
Pleste \\
See \\
footurote \\
below \\
\end{tabular} & & $16-6.02(\mathrm{~A})(1)$ & 16.5 & $16.2(0)^{1}$ & $36.2(2)$ \\
\hline $\begin{array}{l}\text { Rnle of } \\
\text { Confidantisity } \\
\text { or Privileg }\end{array}$ & $16.2\left(c x^{2}\right)$ & & Rile 4(e) & $16.5(c)(2)$ & & & $16-6.04(\mathrm{~A})$ & & $16.2(e)$ & $16.2(t)$ \\
\hline $\begin{array}{l}\text { hoposed } \\
\text { Obligtion of } \\
\text { Good Fith }\end{array}$ & & & Forle of & & & & $\begin{array}{l}16-6.02(B)(1) \\
16-6.05(A)\end{array}$ & & & \\
\hline $\begin{array}{l}\text { Obligutionto } \\
\text { Reppon Beck to } \\
\text { Jodes }\end{array}$ & & & $\begin{array}{l}\text { Roth +(Q) } \\
\text { Repout to } \\
\text { Clest of } \\
\text { Cout }\end{array}$ & & & & $16-6.05(\mathrm{~B})$ & & & \\
\hline $\begin{array}{l}\text { Requinemente of } \\
\text { Full Authority } \\
\text { to Senthe }\end{array}$ & & & Farle $3(0)$ & $16.5(1)(2)$ & & & $16-6.02(B)(1)$ & & & \\
\hline $\begin{array}{l}\text { Senctions For } \\
\text { Noncomolimose }\end{array}$ & & & Fonle 3(e) & & & & $16-6.05(A)$ & & & \\
\hline 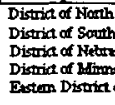 & 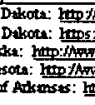 & 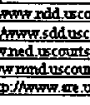 & 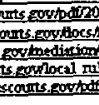 & 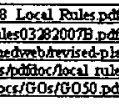 & mpif & Inder so & & & & \\
\hline 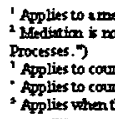 & 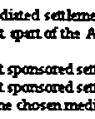 & 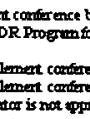 & 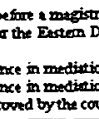 & 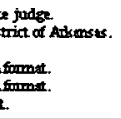 & Set Genteral & Onder No. & 50 (Pletese refirem & ce the section & exteled toth & her ADR \\
\hline 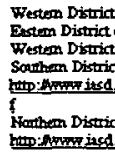 & 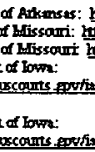 & Acontintons & 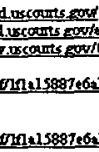 & 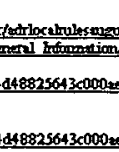 & 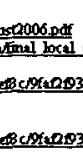 & $\frac{60508 \mathrm{P}}{3001 \mathrm{dal} s}$ & $573 \times 70$ & ATILE & 2000 & OPones.pd \\
\hline
\end{tabular}


IS IT TIME FOR A FEDERAL MEDIATION EXCLUSIONARY RULE?

\begin{tabular}{|c|c|c|c|c|c|c|c|c|c|c|c|c|c|}
\hline \multicolumn{13}{|c|}{ gru CIRCUT, } & \\
\hline & $\begin{array}{l}\text { Distrit of } \\
\text { Idthe }\end{array}$ & $\begin{array}{l}\text { Ditrict } \\
\text { of } \\
\text { Antrone }\end{array}$ & $\begin{array}{l}\text { Distrit of } \\
\text { Montan }\end{array}$ & $\begin{array}{l}\text { District of } \\
\text { Orgoon }\end{array}$ & $\begin{array}{l}\text { Diztri-t } \\
\text { of } \\
\text { Nevoda }\end{array}$ & $\begin{array}{l}\text { Di=trict } \\
\text { of } \\
\text { Hawrail }\end{array}$ & $\begin{array}{l}\text { Cental } \\
\text { Ditrict of } \\
\text { Califonin }\end{array}$ & $\begin{array}{l}\text { Sorthern } \\
\text { District of } \\
\text { Celifornis }\end{array}$ & $\begin{array}{l}\text { Nortsem } \\
\text { District of } \\
\text { Colifominas }\end{array}$ & \begin{tabular}{|l|} 
Eserters \\
Distrit of \\
Coliformin
\end{tabular} & $\begin{array}{l}\text { Ditriat of } \\
\text { Alests }\end{array}$ & $\begin{array}{l}\text { Dietrit of } \\
\text { Gemin }\end{array}$ & $\begin{array}{l}\text { District of } \\
\text { Northem } \\
\text { Morians } \\
\text { lshonds. } \\
\end{array}$ \\
\hline $\begin{array}{l}\text { Existence of } \\
\text { Memplory } \\
\text { Metiotion } \\
\text { Powom }\end{array}$ & $\begin{array}{l}165(c \times 1) \times \\
\text { B) } 8 \\
16.5(x)(2)\end{array}$ & 83.10 & $166(c \times 1)$ & $16.4(e \times 2) \times A$ & $16-5$ & $\begin{array}{l}88.1(10 x \\
21\end{array}$ & $\begin{array}{l}\text { Role } 4.18 \\
4.2 \text { of } \\
\text { General } \\
\text { Onder No. } \\
\text { On.011 }\end{array}$ & $\begin{array}{l}165(b) 8 \\
165(0)(2 x \\
b)\end{array}$ & $\begin{array}{l}\text { Rnte } 2 . \overline{8} \\
6-2\end{array}$ & & $\begin{array}{l}162(2 \times 1) \\
\text { (B) }\end{array}$ & & \\
\hline $\begin{array}{l}\text { Rubo of } \\
\text { Confidentiality } \\
\text { of Privilege }\end{array}$ & $\begin{array}{c}165(\bar{X} 1) \\
.\end{array}$ & & $166(b)(2)$ & $\begin{array}{l}16.4 \mathrm{~B})(1)- \\
(3)\end{array}$ & & $88.1(k)$ & $\begin{array}{l}\text { Rule } 116 \text { of } \\
\text { Generol } \\
\text { Onter No. } \\
\text { omol. }\end{array}$ & 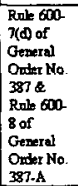 & Rane $612(4)$ & $\begin{array}{l}16-2 \\
271(\mathrm{~m})(1)\end{array}$ & $\begin{array}{l}162(x) 11)- \\
(3)\end{array}$ & & \\
\hline $\begin{array}{l}\text { Impoesd } \\
\text { Obligetion of } \\
\text { Good Faith }\end{array}$ & & & $\begin{array}{l}16.6(b)(4)(A) \\
K^{(B)}\end{array}$ & $16.4(2)(2)(C$ & & $88.1(f)$ & & $\begin{array}{l}\text { Rab 600. } \\
7(\mho \text { of } \\
\text { General } \\
\text { Onder No. } \\
387 \\
\end{array}$ & & & & & \\
\hline $\begin{array}{l}\text { Obligation to } \\
\text { Report Beck to } \\
\text { Jaidg }\end{array}$ & $\begin{array}{l}\text { 16.5(k)1) } \\
\text { Report to } \\
\text { ADR } \\
\text { Administs } \\
\text { ator }\end{array}$ & & & $\begin{array}{l}16.4(3)(1) \\
(2)\end{array}$ & & $88.1(\mathrm{~h})$ & $\begin{array}{l}\text { Rule l1S of } \\
\text { General } \\
\text { Oxder No. } \\
\text { ondil. }\end{array}$ & $\begin{array}{l}\text { Rale } 600 \text { - } \\
7(1) \text { of } \\
\text { Genseal } \\
\text { Onder No. } \\
387\end{array}$ & $\begin{array}{l}\text { Rut 6-14: } \\
\text { Report to } \\
\text { ADR Unit }\end{array}$ & 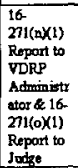 & $\begin{array}{l}162 \times 2 \times(3) \\
\text { (A)(B). }\end{array}$ & & \\
\hline
\end{tabular}

\begin{tabular}{|c|c|c|c|c|c|c|c|c|}
\hline $\begin{array}{l}\text { Require ment of } \\
\text { Fuil A thonty } \\
\text { to Sottle }\end{array}$ & $160(\mathrm{~b}) \times(4)(\mathrm{A}]$ & $16.4(1) \times(2)(F)$ & $88.1(0)$ & $\begin{array}{l}\text { Role } 112 \text { of } \\
\text { Gomerd } \\
\text { Onder No. } \\
07-01 .\end{array}$ & $\begin{array}{l}\text { Rote } 600- \\
7(e) \text { of } \\
\text { Generel } \\
\text { Order No. } \\
387\end{array}$ & $\begin{array}{l}\text { Rule 6. } \\
10(2 \times 1) \times(2)\end{array}$ & $\begin{array}{l}16- \\
21(x) x x \\
A<(B) .\end{array}$ & $\begin{array}{l}16.20)(1) \\
(E)\end{array}$ \\
\hline $\begin{array}{l}\text { Sometions for } \\
\text { Noncomplance }\end{array}$ & $10.6 \mathrm{bKA} 4 \mathrm{~B}$ & $1640 \times 2)$ & & $\begin{array}{l}\text { Fuip iz of } \\
\text { Gemeral } \\
\text { Oder No. } \\
\text { 07-01. }\end{array}$ & 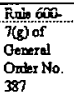 & 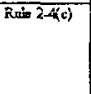 & $\frac{16}{271(\mathrm{p})(2)}$ & \\
\hline
\end{tabular}

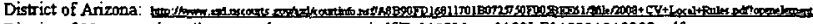

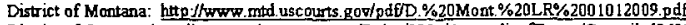

District of Oregon: hittp://www. ord uscourts.gov/Rules/2006/Appendixofforms/Compiled062006.pdf

District of Nevada: htp//www nvd.uscourts.gov/Files/NVUSDistCtRuies06Supp.pdf

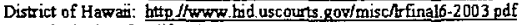

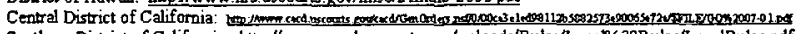

Southern District of Califomia: hup:/WwWw. casd uscourts gov/unloads/Rules/Loca\%20Rules/LocalRules.pdf

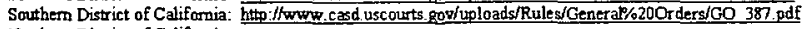

Northem District of California:

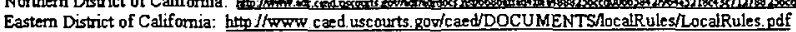

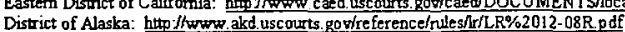

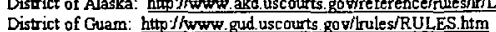

District of Northern Mariana Islands: http:-Jwww nrnid.uscourts. gov/ 
$10^{\text {IE CIRCUIT }}$

\begin{tabular}{|c|c|c|c|c|c|c|c|c|}
\hline & $\begin{array}{l}\text { District of } \\
\text { Nert Mexico }\end{array}$ & $\begin{array}{l}\text { District of } \\
\text { Dyjoming }\end{array}$ & $\begin{array}{l}\text { Distrita of } \\
\text { Reness }\end{array}$ & $\begin{array}{l}\text { District of } \\
\text { Colaredo }\end{array}$ & $\begin{array}{l}\text { Distriac of } \\
\text { Dash }\end{array}$ & $\begin{array}{l}\text { Eestem } \\
\text { District of } \\
\text { Oklthame }\end{array}$ & $\begin{array}{l}\text { Nathem } \\
\text { Distritt of } \\
\text { Oshahoma }\end{array}$ & 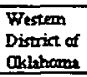 \\
\hline 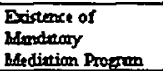 & & $16.3(0)$ & $16.3((x) \overline{1})$ & 16.6 & $16.2(6)$ & $15.24(4)$ & $16.20(x)$ & \\
\hline $\begin{array}{l}\text { Ralel of } \\
\text { Cosfidentivity or } \\
\text { Prisilege }\end{array}$ & & $16.3(c)(2)(\mathrm{i})$ & $16.3(0)$ & & $\begin{array}{l}\text { ADR Ptan: } \\
\text { Section } 3 \text { (a) } \\
\text { (s) }\end{array}$ & & & $16.3(6)$ \\
\hline \multicolumn{9}{|l|}{$\begin{array}{l}\text { of Goosd Obligution } \\
\text { ofith }\end{array}$} \\
\hline $\begin{array}{l}\text { Obligation to Repart } \\
\text { Beds to Judge }\end{array}$ & & $16.3(4)(3) \times(4)$ & & & $\begin{array}{l}\text { ADR Plan: } \\
\text { Section o (a) } \\
\text { Repart to } \\
\text { Clenk of Court }\end{array}$ & & & \\
\hline $\begin{array}{l}\text { Requirement of Full } \\
\text { Autharity to Settle }\end{array}$ & & $16.3(\mathrm{c})(1) \times 0$ & $16.3(c)(2)$ & & $\begin{array}{l}\text { ADR Plem: } \\
\text { Setcion } 6 \\
\text { (0) (1) (3) }\end{array}$ & & & \\
\hline $\begin{array}{l}\text { Senctions fir } \\
\text { Nonscourglimes }\end{array}$ & & $\begin{array}{l}16.3(6)(1)(v i) \times(1 \\
\text { vii) }\end{array}$ & $16.3(c)(5)$ & & $\begin{array}{l}\text { ADR Plan: } \\
\text { Section } 6 \text { og }\end{array}$ & & & \\
\hline
\end{tabular}

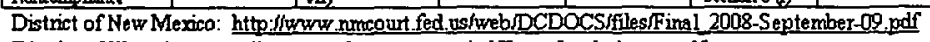

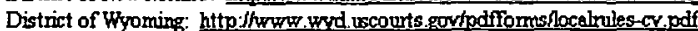

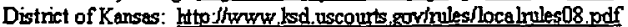

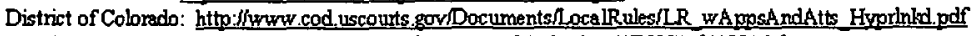

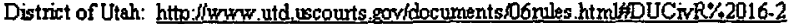

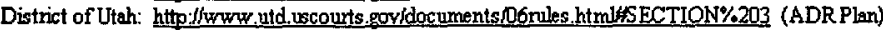

Eastem District of Oklahoma: httpo:/hwowry oked uscounts.govinules_main.htm

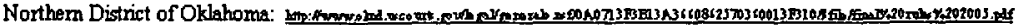

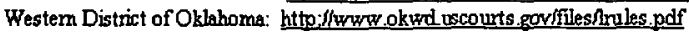

* The District Courts in Oklahoma refer to settlement conferences, rather than mediation.

- 
IS IT TIME FOR A FEDERAL MEDIATION EXCLUSIONARY RULE?

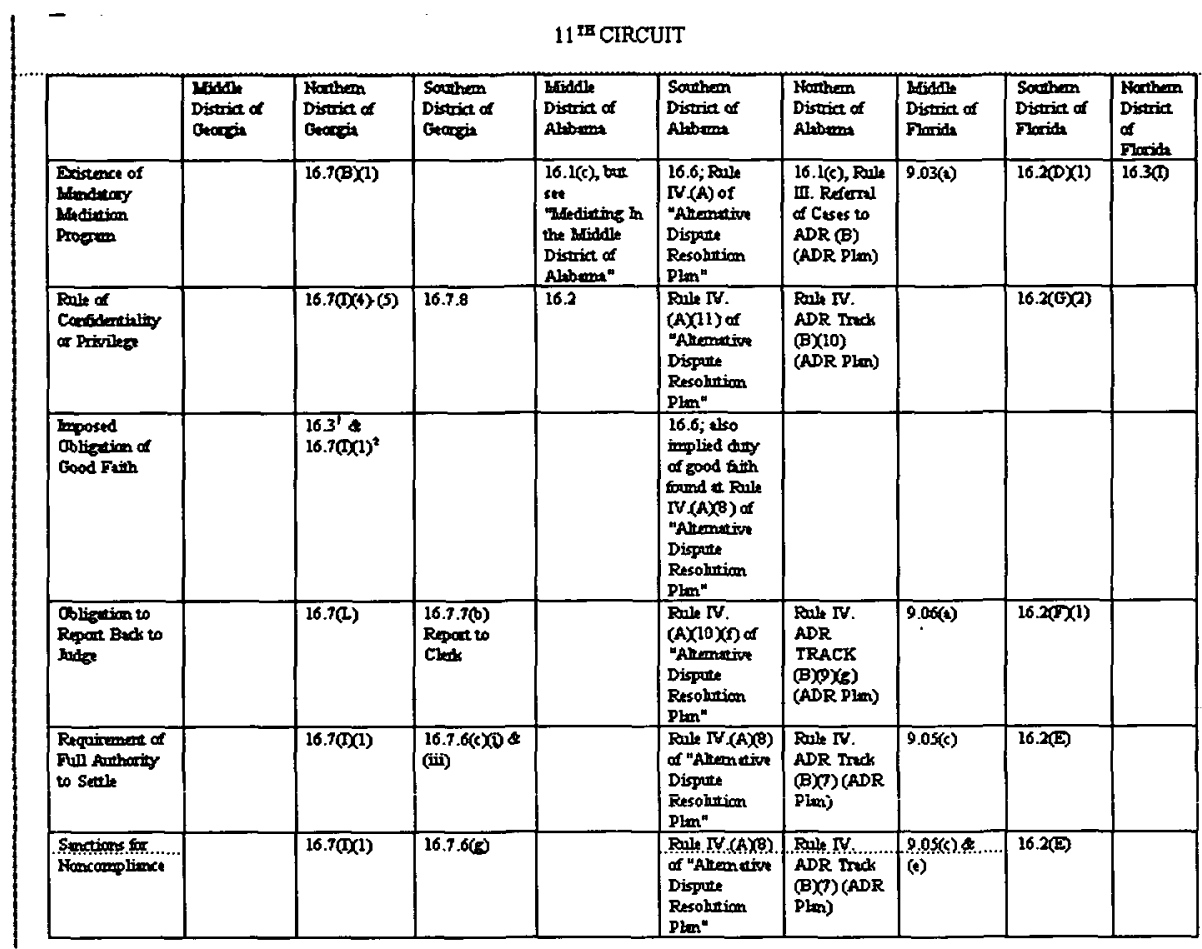

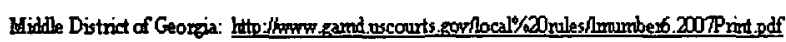

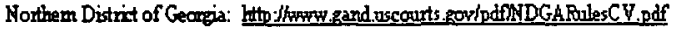

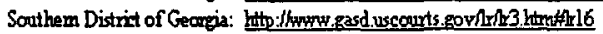

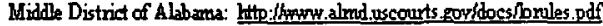

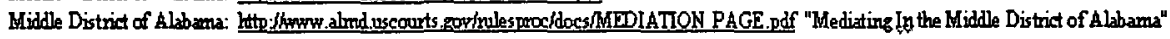

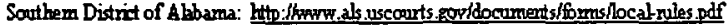

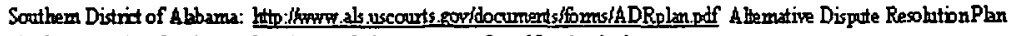

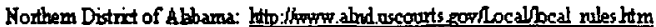

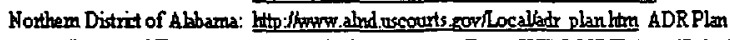

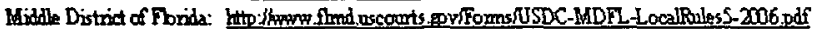

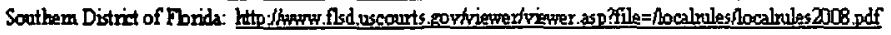

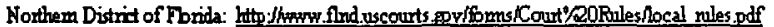




\begin{tabular}{l} 
DISTRICT OF COLUMBIA \\
\begin{tabular}{|l|l|}
\hline \multicolumn{2}{|l|}{} \\
\hline $\begin{array}{l}\text { Existence of Mandatory Mediation } \\
\text { Program }\end{array}$ & District of Columbia ${ }^{1}$ \\
\hline Rule of Confidentiality or Privilege & $84.4(\mathrm{a})(\mathrm{2})$ \\
\hline Imposed Obligation of Good Faith & $84.9(\mathrm{a})$-(b) \\
\hline $\begin{array}{l}\text { See section entitled "Compliance Judge" } \\
\text { under Appendix A entitled "Dispute } \\
\text { Resolution Program." }\end{array}$ \\
\hline Obligation to Report Back to Judge & $84.7(\mathrm{~d})(3)$ \\
\hline Requirement of Full Authority to Settle & $84.8(\mathrm{a})$ \\
\hline Sanctions for Noncompliance & 84.10 \\
\hline District of Columbia: http://www.dcd.uscourts.gov/LocalRules.pdf
\end{tabular} \\
\hline
\end{tabular}

